\title{
CONTRIBUIÇÃO PARA O ESTUDO DA PSICOPATOLOGIA DA AFASIA EM CRIANÇAS
}

\author{
ANTôNIO B. L_EFìvRE *
}

\begin{abstract}
"Il n'y a pas, en effet, de problème qui soulève autant de difficultés que l'aphasie". (Von Monakow e Mourgue, in Introduction Biologique à l'Étude do la Neurologie et de la Psychopathologie.)
\end{abstract}

Poderá parecer supérfluo abalançar-se alguém a realizar, em dias de hoje, uma tese sôbre a afasia. $\mathrm{O}$ assunto tem sido tão estudado, e sôbre o mesmo já existe tal quantidade de publicações, que o estudioso do assunto sente-se desorientado diante de concepções muitas vêzes contraditórias e, mesmo, antagônicas.

Poucos temas absorvem tanto como a afasia. Com razão lembra Ombredane $^{1}$, ao comentar o fundamental trabalho de Baillarger, que os autores mantêm-se tão arraigadamente apegados à sua própria maneira de ver o problema, que novos conceitos emitidos passam freqüentemente despercebidos. Sirva de exemplo para esta crítica o esquecimento quase completo em que permaneceram os trabalhos de Jackson, não obstante tivessem êles reformado de maneira radical os velhos conceitos fundados na ilusão simplificadora do associacionismo.

A multiplicidade de conceitos sôbre a afasia, cada um dêles com ardorosos defensores, explica a grande quantidade de trabalhos publicados. Curioso é, entretanto, observar que, não obstante a vastidão da bibliografia, pouquíssimos são os trabalhos dedicados ao estudo da afasia em crianças. Os compêndios de patologia infantil, mesmo aquêles em que se estuda de maneira especial a neuropsiquiatria, referem-se de maneira inteiramente superficial ao assunto. Para que se tenha idéia de como o tema é pouco estudado, seria suficiente recordar que os "Year-Books" ${ }^{3}$ de pediatria de 1940 a 1948 não citam um único trabalho referente à afasia em crianças. Dir-se-ia que o desprêzo pelo tema daria a medida da importância do mesmo. Não pensamos desta forma, e a justificativa dêste nosso ponto de vista seria um dos motivos que nos levaram a realizar o presente trabalho. O tema nos parece rico e digno de ser explorado, por isto que o quadro clínico da afasia em crianças oferece condições excepcionais para estudo, uma vez que as lesões vão atingir estruturas nervosas em evolução, livres

Tese de doutoramento apresentada à Fac. Med. da Univ. de São Paulo (Cadeira de Clínica Neurológica).

* Assistente de Clínica Neurológica na Fac. Med. da Univ. de São Paulo (Prof. A. Tolosa). 
das alterações parenquimatosas encontradas com tanta freqüência no cérebro dos adultos portadores de arteriosclerose, que forneceram a maior parte dos casos de afasia até agora estudados. Não se diga que esta seria a única razão, uma vez que existem muitos casos de afasia estudados em adultos jovens, nos quais não há qualquer evidência da arteriosclerose. Há outro motivo que constitui, talvez, o maior atrativo para os que pretendem estudar a afasia em crianças. Alguns dos trabalhos publicados sôbre o assunto salientam um fato bastante característico: a rapidez com que evolui a afasia nas crianças, o que torna possível, em curto prazo de tempo, estudar as várias etapas por que passam os processos de desintegração e de recuperação da linguagem. Esstes processos que, no adulto, evoluem lentamente, na criança se desenvolveriam de maneira muito rápida. A evolução de um mutismo quase absoluto para uma linguagem perfeitamente correta se processaria no prazo de poucas semanas; quase que diàriamente os exames de alguns casos oferecem evidências de tal progresso sôbre os exames anteriores, que o observador desavisado pode ficar em dúvida sôbre a validez de suas verificações, e, levando em conta as dificuldades inerentes à neuropediatria, pode ser levado a interpretar os dados patológicos colhidos, mais como deficiências de observação do que pròpriamente como verdadeiros distúrbios da linguagem.

Não pretendemos estudar as chamadas "afasias de evolução", ou seja, os casos em que a linguagem se desenvolve de maneira lenta e defeituosa, em pacientes nos quais há freqüentemente uma debilidade mental, insuficiente, entretanto - é necessário assinalar - para explicar por si só a deficiência do desenvolvimento da linguagem. Nosso trabalho se refere apenas às afasias ocorridas em pacientes com desenvolvimento normal, seja da inteligência, seja da linguagem, até o momento em que o quadro de afasia se manifestou.

Pareceu-nos importante a tentativa de fixar êstes pontos de vista, uma vez que, mesmo em trabalhos recentes, realizados com o maior espírito de objetividade, como o de Nielsen ${ }^{4}$, encontramos a afirmação categórica de que "It is well known that aphasia does not develop in infants from a unilateral lesion regardless of laterality", repetindo, aproximadamente, antiga opinião de Pierre Marie, ponto de vista que entra em choque com o que pudemos observar.

Pensamos, assim, realizar uma contribuição que poderá ser de utilidade para o diagnóstico das afeç̧óes cerebrais em crianças. Limitamo-nos ao relato de pequeno número de casos, aquêles em que pudemos estudar mais detalhadamente os fenômenos afásicos. Deixamos de incluir as observações de outros casos por nós acompanhados na Clínica Neurológica da Faculdade de Medicina da Universidade de São Paulo (Serviço do Prof. Adherbal Tolosa) e em nossa clínica particular, por não têrmos tido a oportunidade de estudá-los de maneira completa. Pareceu-nos razoável publicar apenas algumas das observações realizadas, uma vez que não é nossa intenção fazer um trabalho estatístico sôbre a incidência da afasia como sinal clínico na patologia neurológica da criança. 


\section{EVOLUÇAO DA LINGUAGEM NA CRIANÇA}

A evolução da linguagem da criança tem sido objeto de numerosos estudos; a excelente revisão de McCarthy ${ }^{5}$ cita nada menos de 2.36 trabalhos especializados sôbre o assunto, mostrando que, desde os primeiros fonemas, decorrentes de esforços musculares espontâneos em hiperextensão, coincidindo com a oclusão da glote, até o período da frase gramaticalmente perfeita, há um veio riquíssimo para a investigação.

Pareceu-nos imprescindível breve exposição sôbre a evolução da linguagem, pois só assim poderemos distinguir o que decorre de uma condição patológica, daquilo que corresponde a ııma etapa evolutiva natural.

Os trabalhos sôbre a evolução da linguagem infantil têm sido fcitos de acôrdo com vários critérios. Piaget ${ }^{6}$. Boujarde ${ }^{7}$ e outros trouxeram interessantes contribuições no que diz respeito à elaboração do pensamento lógico e à forma pela qual a criança expõe seus pensamentos. Outros alltores dirigiram suas pesquisas no sentido da observação do desenvolvimento do vocabulário infantil em suas várias etapas. Aos estudos citados no trabalho de revisão feito por McCarthy, devemos acrescentar o trabalho de Heloŕsa Marinho e col. ${ }^{8}$, em que é estudada a evolução da linguagem do pré-escolar brasileiro, contribuição das mais importantes e, no entanto, pouco divulgada nos trabalhos médicos.

As primeiras emissóes de caráter vocálico vão-se tornando progressivamente mais complexas, à medida que as consoantes vão surgindo, passando-se, insensivelmente, para a segunda etapa, que é o periodo silábico. Uma consoante se produz quando a corrente de ar que gera o som fundamental é mais ou menos interrompida no canal vocal, quer pelo estreitamento de seus órgãos, quer por um fechamento momentâneo que cessa bruscamente. Andrée Feyeux ${ }^{9}$ estudou detalhadamente esta fase, relacionando o aparecimento das várias consoantes com o desenvolvimento de uma atividade neuromuscular adaptada para articulações progressivamente mais elaboradas.

E' evidente o caráter lúdico destas emissões silábicas, como muito bem observou McCarthy, que salientou o fato de qus a criança, nesta fase, brinca com a própria voz, exercitando seus parcos mecanismos articulatórios. Através dêstes exercícios, os sons vão adquirindo inflexões cada vez mais variadas, embora pobres sob o ponto de vista expressivo, uma vez que só mais tardiamente vão adquirir um sentido simbólico específico. Estes sons são de caráter meramente reflexo, como afirmam Ombredane ${ }^{10}$ e Fenton ${ }^{5}$, o que não reduz a importância da fase da balbuciação, com seus exercícios articulatórios que desenvolvem os órgãos da articulação e da fonação a tal ponto que, ao fim de pouco tempo, a criança já dispõe de todos os fonemas que serão usados na linguagem desenvolvida do adulto. A riqueza destas articulações parece estar relacionada com a inteligência, segundo Andrée Feyeux; embora não se possa afirmar que tôda a criança inteligente apresente uma balbuciação rica com modulações finas e variadas, parece fora de dúvida que as crianças retardadas a apresentam muitı pobre e monótona. E' imprescindível, no caso desta pobreza da balbuciação se manifestar, co- 
gitar-se da possibilidade da existência de uma hipoacusia que poderia explicá-la.

A consoante $m$ parece ser a primeira a aparecer, donde uma explicação mecanicista para a apelação maternal nos vários idiomas. As consoantes $p$ e $b$ aparecem em seguida. Segundo Shirley ${ }^{5}$, a prineira sílaba aparece na idade de oito semanas. As observações são muito discordantes no que diz respeito ao aparecimento das outras consoantes e das sílabas tornadas possíveis pelas várias combinações com as vogais. Ao que parece, cada criança tem predileção por determinadas sílabas, com as quais se exercita mais habitualmente.

A revisão de McCarthy mostra que os trabalhos antigos, pouco objetivos, conduziam à conviçãa de que a linguagem ia se construindo progressivamente, passando de emissões silábicas simples para outras mais complexas, até ser atingida a fase da palavra completa, de conteúdo simbólico. A objetividade dos estudos modernos mostra que tal forma de evolução não se observa na realidade. A balbuciação infantil é muito rica desde o início, demonstrando grande e precoce plasticidade dos órgãos da palavra, capazes de produzir os sons mais variados, mesmo os inexistentes em qualquer idioma. Dêste aglomerado de sons, como que são escolhidos aquêles que fazem parte do idioma materno para a elaboração do repertório de palavras, o que faz com que a linguagem se enquadre dentro da lei geral estabelecida por Coghill para o desenvolvimento das funções nervosas, na qual está estabelecido que as formas diferenciadas de atividade se individualizam a partir de uma forma global inicial.

A imitação é, para a maioria dos autores, o fator mais importante na aquisição da linguagem. Não pode haver melhor prova para isto do que a grande capacidade da criança em aprender todos os idiomas que ouve e, por outro lado, a falta de desenvolvimento da linguagem nos surdos congênitos.

Já há muito tempo, Taine ${ }^{5}$ havia afirmado que a criança só é capaz de imitar os sons que se haviam apresentado em sua balbuciação espontânea. Este é, ainda, o ponto de vista da maioria dos autores que estudam o assunto, devendo-se apenas recordar que, sendo a balbuciação muito rica e variada, contendo pràticamente todos os fonemas, esta afirmação perde grande parte de seu valor.

$\mathrm{O}$ aprendizado através de treinamento intensivo parece ter pouca importância. Strayer ${ }^{5}$ realizou interessante experiência com dois gêmeos univitelinos: um teve treinamento intensivo durante 5 semanas, no sentido de denominar objetos, e o outro só começou a ter-o mesmo treinamento depois de decorridas estas 5 semanas; demonstrando a importância decisiva da maturidade neuromuscular, verificou Strayer que o treinamento do segundo paciente foi mais ràpidamente eficaz do que o do primeiro.

A observação de vários autores coincide com a experiência leiga corrente de que a criança compreende a linguagem muito antes de poder falar. Esta afirmativa é válida, tanto para as crianças normais, como para os casos patológicos em que há retardo no desenvolvimento da palavra. A com- 
preensão se inicia com relação às situações globais. A palavra falada não é compreendida no início, enquanto que o gesto e a mímica o são; a criança percebe situações globais através da entonação e da melodia du frase, desconhecendo o sentido de cada palavra isoladamente. Só mais tarde, depois desta percepção global estar bem desenvolvida, é que cada palavra vai ser compreendida. A criança procura "adivinhar" o sentido global, segundo a expressão de Ajuriaguerra e Hécaen ${ }^{11}$, sem compreender os detalhes da frase; passa-se com ela o mesmo que a nossa experiência nostra acontecer quando lemos ou ouvimos um trecho em língua estrangeira que não conhecemos bem: procuramos compreender o sentido global, mesmo desconhecendo o sentido de algumas palavras e expressões tomadas isoladamente.

Todos os especialistas puderam observar muitos casos de crianças com retardo mental global, em que a palavra custa muito a se desenvolver, nas quais o exame mostra uma capacidade bastante satisfatória de percepção, francamente contrastante com a grande deficiência de expressão.

Há poucos trabalhos objetivos sôbre a época do aparecimento da primeira palavia, pelo que pudemos deduzir da revisão feita por McCarthy. Gesell e Amartruda ${ }^{12}$, em sua tabela de diagnóstico de desenvolvimento, incluem dentro das atividades correspondentes à $400^{\mathrm{a}}$ semana duas palavras (Papa, Mama) e uma palavra nova. Perez ${ }^{5}$ assinala um ponto que parece ser pacífico: as primeiras palavras que revelam conteúdo simbólico são, em geral, monossilábicas ou monossílabos duplicadios (Má, Mamá, etc.). Isto deve ser recordado ao se planificar a reeducação da linguagem de um afásico, seja criança ou adulto. O plano mais razoável de reeducação deve consistir em iniciar os exercícios com as primeiras sílabas e palavras que aparecem no vocabulárjo infantil, uma vez que elas dependem de mecanismos articulatórios mais simples.

Outra verificação curiosa nesta fase vem a ser o desenvolvimento da expressividade da linguagem dos gestos que, também, precede o desenvolvimento da palavra falada. $O$ gesto na criança assume tal capacidade de expressāo que, com certa freqüểncia, observamos crianças suficientemente dotadas sob o ponto de vista intelectual, que não sentem a necessidade de recorrer à forma verbal de expressão, uma vez que conseguem fazer-se entender perfeitamente pelo gesto. Temos observado casos interessantes neste sentido. Crianças bastante inteligentes que, até o término do segundo ano de vida, não falam pràticamente nada, mas que são capazes de se exprimir com bastante perfeição usando sòmente os gestos e nas quais, logo no primeiro ou segundo mês do terceiro ano, a linguagem se desenvolve de maneira absolutamente correta, Esta nossa observação coincide, aliás, com a de Andrée Feyeux, que chama mesmo a atenção para o valor prognóstico da boa expressividade pelo gesto. Segundo esta autora, pode-se dizer que o prognóstico quanto ao desenvolvimento da palavra é favorável, na criança não surda, sempre que exista boa capacidade de expressão pelo gesto.

A primeira frase é, em geral, constituída por uma só palavra, freqüentemente de caráter imperativo. A palavra, mesmo um substantivo, adquire 
um sentido proposicional. A criança que diz aga em tom imperativo, está dizendo eu quero água.

O desenvolvimento do vocabulário tem sido estudado, tanto sob o ponto de vista quantitativo, como qualitativo. A característica mais nítida nas primeiras etapas vem a ser a grande preponderância dos substantivos. Aos dois anos de idade (fase deriominativa de Koffka) os substantivos representam 50 a $60 \%$ do vocabulário total. Não deixa de ser curioso uin fato tirado de nossa experiência com a reeducação de afásicos: notamos, sempre, uma facilidade muito maior no reaprendizado da fala para a articulação voluntária dos substantivos, do que dos verbos e pronomes; esta observação se enquadra na concepção jacksoniana, no sentido de que as aquisições mais remotas e mais organizadas sofrem menos os efeitos da lesão, ou então, que a reaquisição da linguagem, fazendo-se através do hemisfério direito (nos destros), vai proporcionar oportunidade para assistirmos novamente à sucessão das etapas próprias da evolução da linguagem infantil.

A proporção dos substantivos vai diminuindo à medida que o vocabulário aumenta, ao passo que a dos verbos vai-se tornando progressivamente maior $\left(\mathrm{Grant}^{5}\right)$. Outro caráter que se destaca desde as primeiras fases é a riqueza proporcional das interjeições; já se chegou, mesmo, a propor uma teoria interjeicional para explicar o desenvolvimento da linguagem. Os pronomes pessoais ou relativos e as conjunções são adquiridos mais tardiamente e com dificuldade. E' característica a preponderância da primeira pessoa no início do emprêgo dos pronomes. Os adjetivos são muito escassamente empregados nestas primeiras frases (Bean ${ }^{5}$ ).

As frases são, então, bastante imperfeitas e apresentam deficiências que, sob certas condições, iremos encontrar reproduzidas pela patologia; é, assim, por exemplo, que foi notada evidente tendência perseverativa nestas primeiras frases $\left(\right.$ Shirley ${ }^{5}$, Adams ${ }^{5}$ ), tendência que se vai reduzindo gradativamente à medida que a frase se aperfeiçoa.

Parece ser unânime a verificação de que a linguagem se desenvolve mais precocemente nas meninas do que nos meninos. Stern ${ }^{\check{ }}$ explica êste fato pela maior tendência à imitação observada nas meninas; por outro lado, Ley notou que os distúrbios do desenvolvimento da palavra e da leitura ocorrem com maior freqüência nos meninos do que nas meninas.

Andrée Feyeux sintetiza o desenvolvimento da frase em três etapas principais, condicionadas por diferentes estados psíquicos e motores que as presidem e determinam: 1) a palavra-frase; 2) a frase agramatical (frase "petit nègre"); 3) a frase corretamente construída. Convém recordar que estas etapas só podem ser isoladas de maneira artificial $\epsilon$ didática, pois, na realidade, elas se superpõem e se confundem.

A etapa palavra-frase é superada por mejo de mecanismos de imitação. Através de uma série de ensaios e tentativas aproximadas, a frase condensada vai sendo substituída pela frase de tipo adulto; a emissão de certas fórmulas seguida de alguns resultados obtidos (sentir-se compreendido pelos outros, obtenção de certas concessões, coisas e situações evitadas), determinam o estabelecimento de reflexos condicionados, que são, em 
última análise, o mecanismo ảe formação e desenvolvimento da linguagem como forma de expressão.

\section{CONCEITO DA AFASIA}

Nos trabalhos sôbre a afasia há, geralmente, uma introdução histórica salientando as contribuiçóes trazidas por aquêles que se dedicaram ao assunto. Pretendemos, neste capítulo, apenas sintetizar um conceito de afasia; por isso, não serão referidos vários autores e conceitos consagrados, não pelo fato de considerarmos os trabalhos não citados como de menor valor, mas sim porque é nossa intenção expor o assunto da forma mais sintética e clara possível. Este desejo de simplificar nos afastará da análise de doutrinas já discutidas na época em que foram lançadas e que estão completamente superadas. Acreditamos que, hoje, sòmente um interêsse histórico poderá reter nossa atenção, quer na discussão terminológica dos autores francêses, quer no conceito associacionista do mosaico de centros, já inteiramente ultrapassado desde que Jackson, Bergson, Von Monakow e outros demonstraram, de maneira irretorquível, seu caráter esquemático simplístico, alheio à realidade dos fatos observados na clínica.

0 atomismo psicológico baseava-se na localização, em regiões circunscritas do córtex, de imagens motoras ou impressões sensoriais. Vários esquemas foram propostos, admitindo a existência de centros cerebrais limitados e mais ou menos bem localizados, destinados a uma função específica. O primeiro grande expositor do conceito foi Broca (1861), baseado em estudos anátomo-clínicos que se tornaram clássicos. Esta exposição foi objeto de severas críticas, principalmente da parte de Pierre Marie, não tendo escapado desta crítica nem mesmo as localizações das lesões dos primeiros casos de Broca. A então denominada afemia era atribuída (desde os estudos de Bouillaud), à insuficiência da faculdade de coordenar os movimentos próprios da palavra articulada. As pesquisas eram, nesta época, mais orientadas no sentido anátomo-clínico que no psicofisiológico. Os estudos foram-se acumulando, sendo digno de destaque o trabalho de Wernicke (1874), notável sob todos os pontos de vista. Já era sentida a necessidade de uma síntese quando surgiram os trabalhos de Charcot (1883-1884), cujas idéias podem ser esquematizadas no clássico "schéma de la cloche", sôbre o qual foi edificado, "como que sôbre rocha" (Froment ${ }^{13}$ ), lôda a patologia da linguagem. A concepção de Charcot admitia quatro grupos de imagens da linguagem: as imagens auditivas e visuais verbais, e as imagens motoras articulatórias e gráficas. A destruição de um ou ouiro dos centros em que éstas imagens eram colecionadas, determinaria a perda do estoque de imagens que lhes seriam próprias, condicionando o aparecimento de uma forma particular de afasia. Passando por Pitres e Crasset, a concepção associacionista chegou a Dejerine ${ }^{14}$, o qual, não obstante fizesse sérias restrições ao conceito primitivo de Charcot, continuou admitindo que o afásico motor não falava por ter perdido as imagens motoras da articulação, ou seja, a memória dos movimentos articulatórios. Trabalhos recentes, como 
o de Nielsen, embora arejados pelas novas idéias surgidas depois de 1900, ainda estão contaminados pelo associacionismo simplista; êste autor se refere a um estoque de "engramas", que seria mais ou menos atingido pela lesão determinante da afasia. A linguagem, constituída à custa de "memory pictures" que são armazenadas pelas crianças no processo de aquisição, sofreria de uma forma ou de outra, desde que êsse estoque fôsse atingido pela lesão. Permanece Nielsen, pois, prêso à velha hipótese de Bouillaud da perda da memória dos movimentos articulatórios.

As críticas a êste conceito não se fizeram esperar. Abster-nos-emos de maiores referências ao "conflito em família" dos autores francêses, que culminou com a realização das três sessões da Sociedade de Neurologia de Paris, em 1908. As discussões aí travadas entre autores arraigadamente fixados em seus pontos de vista, a ponto de freqüentemente usarem uma terminologia não coincidente para uma mesma forma de distúrbio da linguagem, deixaram de focalizar os pontos fundamentais do problema que, já há muito, haviam sido esboçados por Baillarger ao comentar, em 1865, o relatório de Lélut a respeito do trabalho de Marc Dax sôbre a localização, no hemisfério esquerdo, dos centros da linguagem.

Trousseau, que inicialmente adotara a concepção de Broca, criticou-a, depois, sob vários aspectos. A primeira crítica incidiu sôbre o têrmo afemia, pois Trousseau, verificando que o têrmo afemia não significa "ausência de fala" e sim "infâmia", lançou o têrmo afasia, que - apesar de impróprio - até hoje perdura. Trousseau criticou, também, a localização da lesão determinante da afasia segundo a descrição de Broca, porém sua crítica mais importante incidiu sôbre o aspecto psicopatológico, que era colocado em plano secundário por Broca. Trousseau notou aquilo que Baillarger observara e que, mais tarde, Jackson desenvolveu em suas conferências. "Il y a, chez les aphasiques, une impossibilité de parler que tient à des causes fort diverses et qu'il est très difficile d'analyser", escreveu Trousseau (cit. por Froment ${ }^{13}$, pág. 1240) impressionado com certos aspectos estranhos do quadro clínico dos afásicos. Qual a razão por que um doente capaz de falar claramente "Bonjour, Monsieur", era incapaz de dizer, em outra ocasião, "Bon bon", para, depois, sair de seu mutismo e pronunciar corretamente "Merci" ou "Je veux m'en aller"? Percebeu Trousseau a insuficiência da concepção atomista, mas não foi muito além de uma vaga explicação baseada na perda das "formules de la pensée", isto é, o meio pelo qual o pensamento se manifesta através da palavra falada, escrita, ou do gesto.

Foi na análise de observações feitas in vivo e não in libris, para usar a expressão de Froment, que se baseou a concepção exposta inicialmente por Baillarger e desenvolvida genialmente por Jackson. O fundamental nesta concepção é a verificação de que, no afásico, o distúrbio consiste na abolição das incitações motoras voluntárias, e a persistência das incitações motoras espontâneas ou automáticas. Trata-se de um fenômeno conhecido, hoje, pela maioria dos neurologistas, mas que, na época, pareceu revolucionário. 
As linhas mestras desta concepção mantêm-se até hoje sólidas, como alicerces sôbre os quais se estruturam os conhecimentos, não sòmente das afasias, como também das apraxias. Os estudos mais sérios sôbre êstes assuntos reconhecem êste fato; seria suficiente recordar - se fôsse necessário provar esta afirmação - que Henschen ${ }^{4}$, cinqüenta anos depois, corno uma das conclusões tiradas de sua extraordinária obra de revisão casuística, afirmou que a não inclusão do hemisfério direito no esquema de explicação dos fenômenos clínicos verificados nos afásicos, poria por terra tôda a estrutura dos conhecimentos sôbre a afasia.

Os fundamentos da concepção jacksoniana estão reunidos na primeira das "Croonian Lectures" ${ }^{15}$, pronunciada, em março de 1884, no "Royal College of Physicians". Tomando de Spencer certas idéias gerais relativas à evolução, expôs Jackson a noção básica de que as moléstias do sistema nervoso devem ser consideradas como processos de dissolução - "dissolution being the reverse of evolution". A evolução pode ser considerada como: 1) Passagem do mais para o menos organizado, isto é. dos centros inferiores, bem organizados, para os superiores, menos organizados; o progresso se verifica dos centros bem organizados desde o nascimento para os mais elevados e em contínua organização durante a vida. 2) Passagem do mais simples para o mais complexo; dos centros mais inferiores para os superiores. Não há incongruência em falar em centros que, sendo, ao mesmo tempo, mais complexos, são menos organizados. Suponhamos um centro que contenha dois elementos sensitivos e dois motores; se êstes elementos estiverem bem ligados entre si, de modo que os estímulos passem ("currents flow") fàcilmente do elemento sensitivo para o motor, éste centro, embora seja anatômicamente simples, é altamente organizado. Por outro lado, podemos conceber um centro que contenha quatro elementos sensitivos e quatro motores, cuja junção seja tão imperfeita que a corrente nervosa encontre muita resistência; êste centro, embora duas vêzes mais complexo, é menos organizado que o primeiro. 3) Finalmente, evolução é a passagen do mais automático para o mais voluntário.

Estes três característicos sintetizam os pontos de vista de Jackson sôbre a evolução das funções nervosas, permitindo concluir que os centros mais superiores, aquêles que são a "base física da consciência", no dizer de Jackson, são os menos organizados, os mais complexos e os mais voluntários. E' com centros desta natureza que teremos de raciocinar ao cuidar dos problemas relacionados com as afasias, e não com centros concebidos simplìsticamente como arquivos em que ficam "fichadas as memórias dos movimentos articulatórios", da concepção associacionista.

Como se processa a dissoluçãa? Para Jackson, sendo a dissolução o reverso da evolução, há, em condições patológicas, passagem do mais voluntário para o mais automático, do menos organizado para o mais organizado, do complexo para o simples. A moléstia determinaria, em sentido inverso, as mesmas etapas observadas na evolução de uma determinada função.

Raciocinando de modo simplista, poderíamos supor que as manifestações observadas na afasia deveriam, conseqüentemente, reproduzir as etapas 
pelas quais passa a linguagem infantil em sua evolução. Low ${ }^{16}$ procurou verificar esta hipótese, estudando, sistemática e minuciosamente, a linguagem infantil e comparando-a com a involução observada nos afásicos. Seu estudo, feito com cuidadoso critério estatístico, não pôde ser concludente, uma vez que foram examinadas poucas crianças. Teríamos o direito de esperar,-raciocinando de acôrdo com a concepção jacksoniana, que a dissolução reproduzisse as etapas da evolução? O próprio Jackson, e mais tarde Von Monakow e Mourgue ${ }^{17}$, Alajouanine, Ombredane e Durand ${ }^{18}$, respondem que não. Com efeito, devemos recordar que a evolução se processa através de etapas ordenadas, obedecendo a uma sucessão previsível. A desintegração das funções, na dissolução, nem sempre obedece a uma sucessão ordenada. Ela se desenvolve no sentido do menos organizado e mais frágil para o mais organizado e resistente, determinando o aparecimento de sintomas conseqüentes à supressão dos níveis mais elevados e à liberação dos mais inferiores, podendo se processar de forma total ou parcial.

$\mathrm{Na}$ primeira, o sistema nervoso sofre de forma global, as primeiras manifestações traduzindo o distúrbio das funções correspondentes aos níveis mais elevados; é o que se observa, por exemplo, na intoxicação produzida pelo álcool, em que se pode notar nitidamente esta maior sensibilidade dos centros hieràrquicamente superiores e a maior resistência dos centros inferiores mais organizados. Paulo Pinto Pupo ${ }^{19}$ demonstrou, pela observação minuciosa dos sinais neurológicos colhidos durante o conıa insulínico, a validez da hipótese jacksoniana da dissolução, uma vez que pôde mostrar o desaparecimento, em primeiro lugar, das funções do sistema neocinético, com libertação do paleocinético, que era atingido quando o coma se aprofundava, libertando os centros hieràrquicamente inferiores.

$\mathrm{Na}$ dissolução local não se verifica, de forma assim esquemática, a supressão das atividades correspondentes aos níveis superiores. Neste caso, apenas uma porção do sistema nervoso é atingida, produzindo fenômenos parciais de dissolução, cuja observação se torna pouco clara, uma vez que, ao lado das manifestações decorrentes da supressão das atividades próprias dos centros mais susceptíveis e menos resistentes e da libertação dos centros inferiores mais organizados, existem manifestações normais das porções não atingidas, que passam, às vêzes, a funcionar de maneira supletiva ou corretiva.

Antes de expor a interpretação dos fenômenos afásicos com base nesta concepção fisiopatológica, necessário se torna breve esclarecimento sôłıre o significado das expressões voluntário e automático, tão freqüentemente utilizadas por Jackson. Recordemos, apenas, que um ato voluntário para um paciente pode ser automático para outro, valendo esta afirmação para as mais variadas formas de atividade práxica e gnóstica. Relatou-nos o Prof. Ombredane o caso clínico de grande compositor francês, vitimado por uma perturbação encefálica, não bem definida quanto à etiologia, mas muito característica no que diz respeito a um quadro progressive de apraxia e agnosia; nos últimos períodos de sua moléstia, quando a gnosia se limitava a mínimas ilhotas perdidas dentro de um alheamento quase completo aos 
estímulos provenientes do exterior, as únicas sensações que chegavam a ser percebidas pela sua consciência eram aquelas relacionadas com a sua própria música; assim é que uma nota falsa, tocada propositadamente, na execução de algumas de suas composições, era percebida imediatamente pelo paciente, que levantava o olhar em direção ao executante, reprovando mudamente o seu deslise. E' claro que, para qualquer um de nós, mesmo em pleno gôzo de nossa capacidade gnóstica, tal deslise ıem seria percebido. A percepção altamente desenvolvida do compositor havia, entretanto, automatizado aquilo que, para um ouvido menos habituado, poderia ser percebido sòmente através de grande esfôrço voluntário.

Esta noção nos parece de grande importância para a interpretação do que se passa nos afásicos. 0 mesmo Prof. Ombredane relatou-nos o caso de um velho professor de filosofia, acometido por uma afasia de expressão e que quase não falava, respondendo às perguntas comuns apenas por monossílabos, interjeições ou emissões esteriotipadas; o paciente sòmente era capaz de formar frases com sentido, quando elas se referiam ao assunto de sua especialidade. A êste respeito, já tivemos oportunidade de demonstrar, num trabalho em colaboração com o Prof. Paulino Longo ${ }^{20}$, a existência de numerosas expressões automáticas em pacientes afásicos.

As manifestações clínicas dos afásicos demonstram, com muita clareza, o acêrto da concepção jacksoniana; talvez, as melhores comprovações desta concepção sejam as manifestações observadas nos afásicos poliglotas. Recentemente tivemos oportunidade de apresentar, na Associação Paulista de Medicina ${ }^{21}$, o registro sonoro das manifestações afásicas de um paciente alemão, residente há cêrca de 30 anos no Brasil, que era capaz de falar perfeitamente o português quando são, e que perdeu completamente o uso dêste idioma de aquisição mais recente depois de se tornar afásico em conseqüência de um traumatismo craniano. As observações publicadas por Alajouanine, Ombredane e Durand ${ }^{18}$ são, também, muito demonstrativas, uma vez que puderam, êstes autores, notar o emprêgo de soluções articulatórias de tipo infantil; fazendo a análise fonética da linguagem de alguns afásicos, descreveram êles a "síndrome de dissociação fonética", caracterizada pelo encontro de algumas formas elocutórias primitivas, observadas normalmente nos primeiros estádios da evolução da linguagem. Em virtude de se tratar de manifestação de uma dissolução local, não poderíamos mesmo esperar encontrar a desintegração em estado de pureza, mas sim como manifestação isolável dentro de um quadro clínico mais complexo.

0 afásico perde a linguagem voluntária, com sentido proposicional, conservando, mais ou menos, a linguagem automática não proposicional; tanto a função expressiva como a perceptiva podem ser atingidas pela desintegração. A dissociação entre a linguagem interna e a externa é descabida, segundo o conceito de Jackson. O que se observa no afásico é a dissociação entre a linguagem voluntária, perdida, e a automática, conservada. Abolida a linguagem voluntária, superior, a linguagem automática fica liberada, exaltada mesmo, algumas vêzes; a linguagem emocional, composta de interjeições, palavras de calão ou de simples inflexões da voz, é freqüentemente encontrada como única manifestação expressiva nas primei- 
ras etapas da evolução de uma afasia. Certo dia, ao encontrarmos na enfermaria para visitar o paciente Rodolfo R. (caso 3), veio ao nosso encontro a irmã que assistia ao menino para, com expressão do mais vivo espanto, nos comunicar que êle deveria estar com o "diabo no corpo", pois, embora fôsse incapaz de responder à mais simples questão, pronunciava corretamente os mais grosseiros palavrões; êsse fato é perfeitamente compreensível se recordarmos sua condição de moleque de rua, dotado de vasto repertório de palavras de calão e habituado ao emprêgo automático desta forma inferior de linguagem.

A linguagem dos afásicos varia muito de um caso para outro, podendo ser de uma pobreza extrema em certas circunstâncias - cm geral, logo após o icto - limitando-se a uma ou outra palavra, que é repetida estereotipadamente. Um de nossos, pacientes, citado no trabalho que publicamos juntamente com o Prof. Paulino Longo ${ }^{20}$, logo após o icto repetia a todo propósito, espontâneamente ou em resposta às mais variadas questóes, apenas as palavras "I Luciano Gualberto", pronunciando-as de forma absolutamente correta, confirmando uma idéia de Jackson, que assinalou o fato de que, muitas vêzes, as palavras residuais são aquelas que o paciente estava em vias de pronunciar no momento de ser acometido pelo insulto cerebral; nada mais natural do que o paciente - um antigo renal - ter querido apelar, quando se sentiu mal, para seu médico assistente. Outras vêzes, estas omissões são muito mais variadas, constituídas por frases que podem ser repetidas com sentido proposicional. Orações, interjeições, palavras de calão, constituem o predominante na linguagem dos afásicos, sendo inteiramente inexplicáveis fora do conceito jacksoniano. 0 paciente a quem se manda dar o nome de uma moeda, um relógio ou outro objeto de uso comum, pode ser inteiramente incapaz de pronunciar a palavra. desejada, mas é capaz de dizer "Meu Deus, eu sei o que é isto!" Algumas vêzes, sob a ação de uma emoção, os pacientes podem pronunciar frases oli palavras de nível mais elevado e com evidente sentido proposicional. $O$ curioso é que tôdas estas emissões são pronunciadas de forma correta, surpreendendo, no início, os familiares dos pacientes. Um de nossos pacientes, embora incapaz de denominar a côr de um cartão, foi, entretanto, capaz de pronunciar corretamente, dirigindo-se à espôsa que assistia ao exame com uma solicitude um tanto ansiosa: "Me deixe sòzinho!" Outras vêzes, principalmente quando a afasia está em regressão e os pacientes vão recuperando o uso da linguagem, a dificuldade expressiva se manifesta de forma característica, notando-se que o paciente tem dificuldade em encontrar as palavras apropriadas, tal como se observa na linguagem de uma pessoa normal que apresente um lapso amnéstico. Vemos, então, o paciente recorrer a certas fórmulas automáticas para conseguir encontrar a palavra procurada. $\mathrm{E}^{\prime}$ assim, por exemplo, que o afásico, incapaz de pronunciar "9 horas" quando lhe é mostrado um relógio marcando esta hora, conta $\mathrm{em}$ voz baixa de 1 até 8 , pronunciando em seguida, triunfante, a desejada resposta.

De forma semelhante aos distúrbios expressivos apresentam-se os receptivos, isto é, da capacidade de compreender, quer as palavras ouvidas, quer 
as lidas. Mesmo nos casos em que as chamadas surdez, ou cegueira verbal são ditas completas, resta sempre ao paciente a possibilidade de compreender as fórmulas cuja percepção lhe é mais automática, ou que mobilizam mais fortemente sua afetividade (sua esfera instintiva, no dizer de Von Monakow), tais como o nome da espôsa, dos filhos, a rua ou a cidade onde moram, etc. Fora destas palavras residuais compreendidas, o paciente pode ouvir tôda uma conversação sem a possibilidade de captar o sentido, tal como se se tratasse de uma língua estrangeira desconhecida. Como conseqüência desta compreensão algumas vêzes apenas parcial de palavras ou frases, o paciente fica limitado a uma percepção global, de caráter aproximado, freqüentemente repleta de erros e defeitos de interpretação. Nestes casos, como é natural, a capacidade de expressão é muito atingida, porém, de forma bastante diferente do que ocorre nos casos em que não há distúrbio acentuado da componente receptiva. $O$ fenômeno da parafasia, en. tão observado, consiste em uma dificuldade para encontrar as palavras adaptadas à situação; elas são, com freqüência, inteiramente deturpadas, uma vez que o paciente junta, ao acaso, sílabas que lhe são mais fáceis de pronunciar, formando, muitas vêzes, um aglomerado de sons que, em seu conjunto, constituem um jargão ininteligível. A parafasia se apresenta, algumas vêzes, sob a forma de uma tendência à perseveração, ou seja, a tendência a repetir sílabas, palavras ou frases que foram pronunciadas de maneira correta anteriormente e que são repetidas, mais tarde, inoportunamente, ou então uma tendência a repetir certas palavras ou trechos de frases que fazem parte das questões que lhe são propostas (ecolalia). Os pacientes dêste grupo freqüentemente "falam" exageradamente, mantendo-se durante longos períodos em verdadeira logorréia, sem sentido proposicional evidente, podendo mesmo ser tomados por dementes, tal a incongruência das palavras e frases, emitidas em fluxo muitas vêzes contínuo.

\section{CLASSIFICAÇAO DOS DISTÚRBIOS AFASICOS}

O problema da classificação dos distúrbios afásicos vem sendo debatido há muitos anos. Poucos assuntos no campo da neurologia têm dado margem a tantas controvérsias, uma vez que as denominações patronímicas se prestam às maiores confusões. Exemplifiquemos com o que se passa com a chamada afasia de Broca. Pierre Marie, Foix, Souques e outros admitiam como afasia apenas a forma chamada de Wernicke, devendo os distúrbios articulatórios ser incluídos no grupo dos distúrbios anártricos; a afasia de Broca seria, para êstes autores, o conjunto f̂ormado pela afasia de Wernicke e anartria. Para Dejerine e sua escola deve-se reservar a denominação de afasia de Broca para a forma predominartemente motora; a afasia de percepção seria chamada de Wernicke, e a afasia total, a soma de uma afasia de Broca com a de Wernicke. Aliás, já em 1908, na discussão sôbre afasia realizada na Sociedade de Neurologia de Paris, como acentua Froment ${ }^{13}$, era impossível uma concordância de idéias a êsse respeito, uma vez que "les mêmes mots n'avaient plus, de l'un à l'autre, le même sens". 
Parece-nos que não há cabimento em uma filiação extemporânea às escolas neurológicas que disputavam, há quarenta anos, em tôrno da denominação das afasias. Aceitamos plenamente a simplificação proposta por Weisenburg ${ }^{22}$, para o qual se deve reconhecer a existência de três grandes grupos de distúrbios afásicos: 1) Distúrbios predominantemente expressivos da palavra falada ou escrita; 2) Distúrbios predominantemente receptivos; os distúrbios expressivos seriam, aqui, de um tipo diferente daqueles incluídos no primeiro grupo - parafasias; 3) Formas mistas expressivo-receptivas, em que pode predominar um ou outro dêstes componentes. Foi considerado, outrossim, um quarto grupo, no qual os distúrbios têm, como principal característica, a dificuldade de evocar palavras com um sentido denominativo para objetos. Devemos salientar que a classificação proposta por Weisenburg não é fruto de um arbitrário agrupamento de formas clínicas, mas sim de longa e paciente análise de vasta casuística.

\section{LOCALIZAÇAO DAS LESÕES}

Qual o resultado de tôda a longa série de discussões que se vêm travando há mais de um século sôbre a localização das lesões determinantes das afasias? Constitui, hoje, ponto pacífico a noção exposta, em 1836, por Marc Dax, que estabelecia ser o hemisfério esquerdo (nos indivíduos destros) a sede da lesão causadora da afasia; pràticamente, todos os trabalhos anátomo-clínicos são unânimes neste particular.

A localização das lesões correspondentes aos diversos tipos de afasias tem sido objeto de numerosos debates desde a apresentação dos famosos estudos anátomo-clínicos de Broca. E' evidente que a existência de divergências neste terreno não pode surpreender a qualquer estudioso do assunto; seria estranhável se houvesse acôrdo em um detalhe assim importante de tão debatido problema.

Parece-nos que o que deve ser analisado é o critério errado - criticado principalmente por Von Monakow - que domina a maioria daqueles que têm estudado anátomo-clìnicamente as afasias com um espírito simplista limitado, quase que exclusivamente, à observação de manifestações clínicas que são relacionadas, de maneira rígida, às lesões encontradas na necrópsia. Mesmo autores recentes, como Nielsen - que realizou extensa revisão casuística - incidem no êrro apontado por Von Monakow.

A concepção de Von Monakow pode ser sintetizada em sua clássica imagem da "caixa de música". Onde está localizada a música nessa caixa, pergunta êle? 0 problema que os localizacionistas näo resolveram reside no fato de que os processos da linguagem se desenvolvem no tempo, o que cria uma dificuldade muito grande para a pretensão de se estabelecer uma localização espacial.

Realmente, devemos admitir que há inaceitável espírito simplista dominando aquêles que pretendem relacionar, rígida e diretamente, o distúrbio de uma função de hierarquia tão complexa como a linguagem, com uma lesão anatômica. A observação detalhada do que se passa com um afásico 
mostra como é variável a manifestação clínica de uma afasia. E' difícil mesmo poder-se imaginar que um afásico seja igual a outro; indo mais além, diremos que o comportamento de um afásico varia tanto de um momento para o outro que as observações que dêles fazemos devem ser, em geral, extensas para poderem ser suficientemente claras.

Já há muito se sabe da influência que a emoção exerce sôbre a linguagem, seja do homem normal, seja do afásico. Sabendo-se que a tensão emocional está, muitas vêzes, exagerada nos pacientes, e levando-se em conta a ação da diásquise nas primeiras fases da instalação da lesão e, mais tarde, do processo ativo de auto-reparação, chegaremos à conclusão que sòmente com muito artificialismo poderemos estabelecer rìgidamente a relação: lesão - manifestação clínica da afasia.

Vejamos como Von Monakow define a diásquise. Suas palavras, quase textuais, são as seguintes: Trata-se de uma forma especial de choque, que sobrevém com freqüência - embora não obrigatòriamente - de maneira súbita; seu ponto de origem é a lesão focal, e sua extensão se faz de acôrdo com vias bem definidas, ao longo de fibras que partem dos arredores imediatos ou do próprio foco lesional. A conseqüência consiste no aparecimento de uma série de fenômenos à distância, sempre na direção das fibras interrompidas. Estes distúrbios são inexplicáveis pelo estatismo mecanicista das antigas concepções. A diásquise seria responsável por sintomas temporários e sua ação se faria notar pela elevação do limiar de excitabilidade das regióes relacionadas com esta linha de expansão do choque lesional. Os sintomas residuais correriam por conta das lesões estabelecidas, das degenerações anatômicas secundárias. A noção de diásquise é inseparável da de localização cronógena de uma função. Em geral, a função atingida em primeiro lugar é a de hierarquia mais superior, a mais voluntária e a mais dèbilmente organizada; no processo de recuperação é ela a que se restabele. ce em último lugar. Entretanto, a diásquise não atua de maneira mecânica; trava-se, depois de instalada a lesão, uma luta ativa para a criação de um novo estado de coisas que permita a adaptação do indivíduo ao meio. Não entrando na análise da concepção, algo metafísica, da "syneidesis", devemos reconhecer a riqueza de sugestões que se encontra no conceito de recuperação exposto por Von Monakow.

Recordemos, também, que muito pouco valor se atribui, em geral, ao comportamento funcional da substância nervosa situada para fora da lesão, privada de suas conexões normais e lutando para reparar o distúrbio funcional provocado pela lesão. Esta noção não se opõe ao conceito de desintegração de Jackson, antes o enriquece, mostrando o fenômeno clínico em tôda a sua complexidade, uma vez que, ao lado do processo de desintegração, observamos, também, os efeitos de um processo ativo, embora defeituoso, de reintegração. E' êste conflito entre a desintegração produzida pela moléstia e a reintegração resultante da ação biológica reparadora, tendente a restabelecer o equilíbrio desfeito pela lesão, que justifica a afirmação de Von Monakow de que há "doentes" e não "tipos mórbidos de sintomatologia rígida". Este fator de reintegração obedece, em sua ação, à lei da economia 
de utilização da energia nervosa (Von Monakow e Mourgue), sofrendo a ação de um sem número de condições difíceis de serem reconhecidas e avaliadas: natureza do processo patológico, condições de vascularização, subordinação a elemento organovegetativos variáveis (doente recém-desperto, sonolento, em vigília, etc.), influência psicológica do meio, disposição de enfrentar e superar os efeitos da doença, fadiga, etc. $O$ paciente a que já nos referimos linhas acima, do qual fizemos um registro sonoro, mostrou, de maneira muito clara, a influência do fator emocional; ao iniciarmos a gravação, o paciente mostrou-se de tal forma emocionado que o registro pareceu-nos, por momentos, totalmente impossível; usamos, então, de um expediente que consistiu em simular que o aparêlho estava desligado e "tentarmos uma vez apenas para fazer um ensaio". O expediente surtiu efeito. 0 paciente que, poucos momentos antes, mostrava-se incapaz de pronunciar qualquer palavra - até para ler o que êle mesmo havia escrito - tornou-se imediatamente loquaz, leu uma carta de três páginas, apenas com pequenos lapsos, e respondeu a várias questōes feitas no momento. Em última análise, o que se passa, em tais circunstâncias, é um exagêro daquilo que observamos em certos oradores improvisados, que se mostram, muitas vêzes, incapazes de falar quando sob a ação da emoção, cometendo lapsos, dos quais nem chegam a tomar conhecimento.

Consideramos simplista e afastado da realidade o intuito de se tentar localizar rìgidamente as lesóes determinantes de formas especiais de afasias. Não podemos admitir que processos de um dinamismo tão complexo, variáveis sob a influência de tantas condições, possam ser relacionados friamente com uma lesão encontrada na necrópsia. O sofrimento de uma porção mais ou menos extensa do cérebro, a influência de estados emocionais e inúmeras outras circunstâncias, devem intervir de maneira tão importante na determinação das características próprias de um quadro afásico, que estaremos seguramente nos iludindo quando esquecemos de todos êstes elementos ao relacionar distúrbios funcionais tão complexos com as lesóes encontradas na necrópsia.

A atitude de autores recentes a respeito do assunto é inteiramente contraditória. Weisenburg, que pode ser considerado como um dos mais profundos conhecedores do assunto entre os neurologistas americanos, é extremamente discreto em sua tendência localizatória. Este autor limita-se a localizar as lesões determinantes das formas expressivas na porção anterior do cérebro e, em menor extensão, nos lobos parietal e temporal; as formas receptivas, por sua vez, são produzidas por lesões sediadas principalmente em áreas parietotemporais e, em menor extensão, na porção anterior do cérebro. Já Nielsen, que, além de excelente revisão casuística, publicou vários e bem estudados casos pessoais, coloca-se em extremo oposto; sua tendência localizatória extremada leva-o a indicar a localização das lesões, não apenas dos quadros clínicos clássicos em seu conjunto, mas até de manifestações sintomáticas nêles isoláveis. 0 trabalho dêste autor, notável sob muitos pontos de vista, carece de uma visão global do problema, incidindo, por esta razão, em artificial fragmentação de sintomas que são, em seguida, 
relacionados diretamente com as achados necroscópicos; sua tendência localizatória chega ao ponto de especificar áreas cuja lesão deveria determinar distúrbios da gnosia musical, auditiva ou visual, e mesmo, uma zona relacionada com a memória dos movimentos da escrita, tal como um teórico associacionista do passado.

Preferimos ficar com aquêles que, reconhecendo a complexidade das manifestações afásicas, limitam a localização das lesões a um plano mais geral, que apenas aponta as grandes linhas que separam as formas expressivas das receptivas. Tal afirmação constitui, talvez, uma confissão de fracasso; agrada-nos, entretanto, lembrar que Ajuriaguerra e Hécaen, em recentíssimo estudo sôbre o córtex cerebral, não nos oferecem qualquer avanço concreto sôbre as localizações gerais expostas no trabalho de Weisenburg.

\section{AFASIA EM CRIANCAS}

O estudo da afasia em crianças pareceu-nos interessante por várias razões, algumas das quais já foram apontadas.

O sistema nervoso infantil oferece condições excepcionais para o estudo da afasia, uma vez que a grande maioria dos trabalhos clássicos foram feitos em pacientes portadores de extensas e múltiplas encefalomalácias, capazes de determinar conseqüências que devem interferir sôbre a pureza que seria desejável nos quadros clínicos. Outro motivo que nos levou a estudar a afasia em crianças foi a curiosidade de observar como se processa a desintegração num sistema nervoso em fase de ativo processo de integração de uma função complexa como a linguagem. Interessou-nos, também, a possibilidade de analisar a capacidade de recuperação, que parece ser grande na criança, segundo a maioria dos autores que pudemos consultar. Outro motivo que nos levou a tentar realizar êste estudo, por tantos motivos difícil, foi a extraordinária pobreza da literatura a respeito.

Os tratados de neurologia ${ }^{23}$ a 39 mantêm um silêncio quase total sôbre o problema das afasias em crianças; mesmo as monografias sôbre as afasias ou sôbre os distúrbios da linguagem em geral, fazem referência as mais superficiais, quando o fazem, sôbre o tema em estudo nesta tese. $O$ mesmo se diga dos compêndios dedicados ao estudo da neuropsiquiatria infantil ${ }^{40}$ a 50 ; em todos êles, o assunto é encarado sem um espírito de análise que procure investigar a existência de características próprias nos quadros de afasia apresentados por crianças. Consulte-se, a propósito, o capítulo sôbre a patologia da linguagem escrito por Travis ${ }^{49}$ no Manual de Psicologia da Criança, organizado por Murchinson; o assunto é aí exposto de forma semelhante àquela encontrada nos compêndios que estudam a neurologia do homem adulto.

O assunto parece-nos completamente descuidado, muito especialmente em nosso meio. Não nos surpreende mesmo deparar com afirmações como a de Nielsen, citada na introdução dêste trabalho; não sabemos, entretanto, como o autor pôde afirmar com tanta segurança êste fato, uma vez que a 
bibliografia, inclusive a extensa bibliografia citada em seu próprio trabalho, é, neste particular, de uma insuficiência evidente e, muitas vêzes, contraditória.

Para West ${ }^{50}$, as afasias existem nas crianças, sendo, contudo, de difícil diagnóstico, uma vez que não se pode fazer distinção exata entre os distúrbios de função e as incapacidades fisiológicas condicionadas pelas várias etapas do desenvolvimento.

As afasias na infância, ao que se pode deduzir da literatura, parecem ser bastante raras; não nos referimos, é claro, à ausência ou deficiência do desenvolvimento da linguagem, ligadas ou não às encefalopatias infantis, nem a êstes curiosos e dificilmente compreensíveis casos de audimutismo a que se refere Ley ${ }^{51,52}$ ou mesmo aos de retardo do desenvolvimento da palavra em crianças com nível intelectual normal, como o caso publicado por Irwin ${ }^{53}$, embora alguns autores os incluam no grande grupo das afasias.

Temos observado alguns casos de afasia em crianças, tanto na Clínica Neurológica da Faculdade de Medicina como em nossa clínica particular. Como não é nosso intuito fazer estatística mas sim um estudo analítico de alguns casos que puderam ser melhor estudados, não referiremos tôdas as observações que fizemos; alguns dos casos não ofereceram condições para um exame satisfatório, por falta de colaboração dos pacientes ou pela transitoriedade do distúrbio, com rápida evolução para a recuperação da linguagem.

Não incluímos aquêles casos em que os distúrbios da linguagem se apresentaram em moléstias que acarretaram sofrimento cerebral extenso e grave; nestes casos, só artificialmente poderíamos isolar um quadro afásico no conjunto sintomático devido ao sofrimento global das funções encefálicas superiores. Esta ressalva parece-nos importante, pois, na literatura que pudemos consultar, encontram-se trabalhos em que são estudadas como afasias, tanto as formas congênitas de deficiência de desenvolvimento da linguagem (em geral ligadas às encefalopatias infantis), como as deficiências da linguagem nas afeç̧ões que determinam sofrimento cerebral grave e generalizado.

Mantero e Hasan ${ }^{54}$ publicaram um trabalho em que são estudados 10 casos de afasia em crianças, com um critério quase que exclusivamente estatístico; os autores afirmam que, na grande maioria dos casos, foi possivel fazer o diagnóstico de "afasia de Broca" (afasia total), embora as observações - tal como foram publicadas - não ofereçam margem para a análise do tipo de afasia. Apenas uma das observações (caso 10) oferece alguns detalhes sôbre as manifestações da afasia, encontrando-se nela referências a uma estereotipia. Relatando a experiência colhida no estudo dêstes 10 casos, os autores insistem na transitoriedade das manifestações afásicas das crianças, em virtude de não existirem nelas encefalomalácias decorrentes de más condições circulatórias; para êles, a duração da afasia nas crianças é, em geral, de 1 a 3 semanas, constituindo as moléstias infecciosas a etiologia mais comum. Para Mantero e Hasan, a recuperação é, em ge- 
ral, boa, desaparecendo em primeiro lugar os distúrbios amnésticos e agnósticos, e, mais tardiamente, os anártricos. $O$ trabalho dêstes autores é muito sintético no que diz respeito à exposição dos detalhes do quadro afásico; poderíamos atribuir a êle apenas um valor estatístico, anotando o registro de seus 10 casos. Mesmo isto, entretanto, não nos parece possível, uma vez que os autores não tiveram o cuidado de limitar o assunto, rotulando como afásicas as manifestações de sofrimento cerebral de um caso de meningoencefalite tuberculosa, em paciente provàvelmente em estado subcomatoso, pelo que podemos deduzir da leitura da observação.

Tal falta de critério seletivo é observada em outros trabalhos, como os de Heuyer e Ledovici ${ }^{55}$, que apresentaram à Sociedade de Neurologia de Paris, em 1947, um caso de afasia ("aphémie") em paciente portador de encefalopatia infantil por trauma obstétrico, com consequiente hemiplegia direita e falta de desenvolvimento da palavra. Em trabalho anterior o mesmo Heuyer, em colaboração com Duchenne e Roumajon ${ }^{56}$, apresentou outro caso semelhante, de hemiplegia direita com "afasia motora" em paciente portador de encefalopatia infantil; os autores justificam a publicação dêstes casos tendo em conta a raridade das observações sôbre as afasias em crianças, lembrando mesmo que "il n'existe en effet que quelques rares observations" sôbre o assunto. Esta opinião funda-se na de Pierre Marie, que considerava a af asia como um sintoma ausente, sob certas condiçôes, nas hemiplegias infantis, uma vez que "tous les auteurs, qu'ils soient neurologistes ou pédiatres, sont d'accord sur ce fait que les enfants atteints d'hémiplegie droite, ne présentent jamais d'aphasie, à condition que cetie hémiplegie droite ce soit produite dans les toutes premières années qui suivent la naissance". Consideramos estranha esta afirmação do grande neurologista francês, que se deve ter fundado, ao admití-la, mais em algum conceito teórico do que em experiência colhida junto aos doentes, pois não podemos supor que tenha escapado à observação de Pierre Marie uma ocorrência clínica que já observamos repetidas vêzes em nossa pequena prática.

$\mathrm{Na}$ própria literatura médica francêsa, tão fértil em estudos sôbre a afasia, encontraremos, alguns anos depois de Pierre Marie, observaçōes que contrariam êste ponto de vista tão taxativo. Em 1939, Girardier e Jeannin ${ }^{57}$ publicaram a observação de um caso de afasia em seguida a fratura do crânio, em criança de 7 anos, chamando a atenção para a raridade da afasia como sintoma neurológico isolado em tais casos; êstes autores citam um estudo estatístico feito por Sorrel e col. em 1937, baseado em 109 casos de fraturas do crânio em crianças, no qual foi assinalado apenas um caso de afasia, estudado por André Thomas ${ }^{58}$, em 1935. No caso descrito por Girardier e Jeannin houvera afundamento ósseo na região temporal esquerda e, ao fim de três dias, o paciente apresentou um quadro de afasia mista, aproximada da forma de afasia amnéstica de Pitres; a criança tinha dificuldade em encontrar as palavras, incapacidade de ler seu livro escolar e de escrever, inclusive seu próprio nome, reduzindo-se sua escrita a alguns traços informes; o vocabulário estava muito reduzido, sendo a criança, entretanto, capaz de falar e repetir perfeitamente as palavras que ouvia, sem 
parafasia, jargonafasia ou surdez verbal. A lesão sediava, segundo tudo levava a crer, na parte posterior das duas circunvoluções temporais, mais exatamente da segunda.

O caso estudado por André Thomas, Sorrel e Sorrel-Dejerine referia-se a interessante forma de afasia expressiva, sem qualquer déficit perceptivo, em paciente com 6 anos de idade. O caso tinha, de notável, a pureza do distúrbio do componente expressivo da linguagem, bem como a evolução rápida para a melhora, uma vez que, oito dias após a intervenção, que mostrou grande hematoma na parte mais inferior da circunvolução frontal as. cendente, o paciente falou a primeira palavra ("mama"), sendo capaz de formar pequenas frases de uso mais ou menos automático aos 12 dias do pós-operatório ("J'ai faim, j'ai soif"); unı mês depois, o vocabuláric era bem grande, embora a criança apresentasse muitos lapsos de tipo amnéstico. 0 paciente nunca teve disartria, não obstante a paralisia facial de tipo central que apresentou.

O trabalho mais completo que pudemos consultar foi o de Gutman ${ }^{59}$, que estudou o problema sob vários aspectos. O primeiro intuito dêste autor foi o de estabelecer uma distinção entre as afasias adquiridas e as congênitas, salientando a grande confusão reinante no assunto, alguns autores negando a existência da afasia em crianças (Cottard) e outros confundindo as formas adquiridas com as congênitas, não obstante já tivesse a clássica monografia de Freud, em fins do século passado, esclarecido perfeitamente êste aspecto do problema. 0 trabalho de Gutman obedece a rigoroso critério seletivo, não sendo consideradas as afasias ocorridas nas encefalopatias infantis e as conseqüentes aos processos toxinfecciosos, excluindo, assim, a interferência de uma debilidade mental ou de um sofrimento cerebral grave generalizado; estuda o autor, apenas, as afasias verificadas em crianças com desenvolvimento psicomotor normal, nas quais a afasia se desenvolveu como conseqüência de lesão dos hemisférios cerebrais. Foram observados 30 pacientes com lesōes nos hemisférios cerebrais, sendo 16 do hemisfério esquerdo, 13 do direito e um com lesões bilaterais; apresentavam afasia 14 dos casos com lesão do hemisfério esquerdo, apenas um dos que tinham lesão à direita (provável contra-golpe) e o único caso de lesão bilateral.

Insurge-se Gutman, com óbvias razões, contra a idéia sustentada pelos autores francêses, mesmo dos mais recentes, de que a afasia é um fenômeno raro nas crianças; o que há, para êle, é falta de conhecimento do quadro clínico. Em síntese, o que Gutman pôde observar em seus casos foi o seguinte: na criança não há, como no adulto, a queixa de dificuldade da palavra, nem se nota grande número de lapsos na denominação de objetos, sendo o quadro dominado pela falta da fala espontânea, falta esta que, freqüentemente, passa despercebida na criança apática e tímida; nota-se, também, empobrecimento do vocabulário e o emprêgo do estilo telegráfico, tal como se observa nos processos de recuperação das afasias do adulto. Gutman cita, em abono de suas idéias, a opinião de Poetzl, que observara a ausência, na criança, da logorréia comum nos afásicos adultos. 
Os casos de Gutman mostraram, como principal característica e independentemente da sede da lesăo, redução da palavra espontânea, que varia desde o mutismo completo até a relutância para falar. A relação sintomatologiasede da lesão é difícil de ser estabelecida. Parece, entretanto, que há uma relação idade-tipo quanto ao distúrbio afásico; abaixo de 10 anos de idade as lesões produzem uma redução mais intensa da linguagem espontânea; acima desta idade (o autor estudou casos até 14 anos) o quadro tende a se aproximar do tipo adulto. Apenas dois casos apresentaram distúrbios da percepção. Com relação ao prognóstico, Gutman conclui que, se fôrem notadas manifestações afásicas 4 semanas após a instalação do quadro. o prognóstico deve ser reservado, embora seja possivel uma recuperação mais tardia. Os pacientes de Gutman foram estudados sob o ponto de vista da determinação do nível mental, tendo sido verificado que só apresentaram déficit intelectual os casos em que houve grande sofrimento cerebral.

Pensamos, com Gutman, que é necessário, antes do mais, distinguir as afasias adquiridas das congênitas, pois estas não representam a desintegração de uma função primitivamente normal, mas traduzem uma integração realizada lenta e defeituosamente. Os dois temas são inteiramente distintos sob todos os pontos de vista que os encaremos, quer etiopatogênico, quer sintomatológico, assim como quanto ao prognóstico e tratamento. Parece-nos fundamental deixar bem claro êste ponto, pois mesmo em trabalhos recentes e especializados como o de Nance ${ }^{60}$, não ficou bem nítida a distinção entre as afasias adquiridas e os retardos de desenvolvimento da linguagem.

Não pretendemos cuidar das afasias congênitas ou dos retardos do desenvolvimento da palavra; interessa-nos, neste trabalho, apenas o estudo das afasias adquiridas por crianças que dispunham de uma linguagem normal até a época em que se instalou o distúrbio.

Caso 1 - Maria do Carmo S., menina de 1.4 anos, brasileira, branca, com desenvolvimento psicomotor normal, sem antecedentes neuropsiquiátricos, que frequientava - $4 .^{\circ}$ ano do ginásio por ocasião do acidente que sofreu. No dia 24 de setembro de 1949 recebeu, acidentalmente, um tiro de revólver na região parietal esquerda; como consequiência, ficou em estado de torpor acentuado durante 2 a 3 dias e, como não apresentasse melhoras, foi internada no Hospital São Paulo, onde ficou sob os cuidados do Dr. Aloisio Matos Pimenta. O exame na ocasião da internação mostrou paciente de constituição robusta, apresentando o ôlho esquerdo fechado por edema hemorrágico e um curativo craniano. Ao exame não foram observadas paralisias, estando a paciente em torpor, em parte devido a medicamentos tomados durante a viagem. A radiografia do crânio mostrava extensa zona de fratura com levanta. mento de retalho ósseo; a bala localizava-se na região occipital, próxima à pele; notavam-se várias esquírulas ósseas na profundidade, em correspondência ao orif́cio de entrada da bala. Foi indicada a operação com a finalidade de retirar as esquírulas ósseas e proceder à limpeza do tecido traumatizado, sendo a craniotomia feita no mesmo dia em que se deu a internação. Levantando o retalho cutâneo, foi verificado que a parte óssea estava deslocada para fora na porção superior, de onde saía massa cerebral. A parte óssea fraturada tinha forma quadrangular e foi retirada como um retalho osteoplástico. A dura-máter apresentava, na suá parte anterior, o orifício de penetração da bala e, na posterior, em dois terços do campo operatório, apresentava-se rôta; ela foi aberta, sendo aspirado o tecido traumatizado, e retirados vários seqiiestros ósseos da profundidade, alguns dos quais relacionados com artérias de regular calibre, que foran coaguladas ou fechadas com "clips". 
Foi retirada a bala, que estava encravada no ângulo póstero-interno das linhas de fratura. Feita a hemostasia, a dura-máter foi fechada após desdobramento parcial, sendo recolocado o retalho ósseo.

No dia seguinte, a capacidade de expressão da doente era quase nula, embora seus familiares tivessem a impressão de que ela entendia o que se the falava. Em certo momento falou claramente "Fuz favor. Dá água". Outras vêzes, saía do torpor para pronunciar palavras incoerentes. Três dias depois de operada verificou-se que a paciente apresentava nítido quadro de afasia mista expressivo-receptiva, parecendo não entender, pràticamente, nada do que se lhe falava. Repetia "Eu quero... Eu quero..." sem ser capaz de terminar a frase. No quarto dia estava melhor e consciente, reconhecendo as pessoas; o exame neurológico não mostrou paralisias ou paresias. A percepção parecia estar melhorada e a expressão era muito variável; ora a pacinte mantinha-se em mutismo quase total, ora era capaz de falar corretamente. No $7 .^{\circ}$ dia de pós-operatório, o quadro afásico apresentava, também, distúrbios de tipo amnéstico. Diante de várias respostas contraditórias apresentadas para uma questão, a doente era capaz de reconhecer a resposta certa, não sendo, entretanto, capaz de enunciá-la espontâneamente. No $9 .^{\circ}$ dia, foi possível reconhecer a existência de uma alexia. A paciente teve alta cirúrgica no $25 .^{\circ}$ dia, procurando-nos a conselho do Dr. Aloisio Matos Pimenta *

Por ocasião de nosso primeiro exame nada de anormal foi notado para o lado dos membros: nenhum sinal de paralisia ou paresia, sendo normais os exames das motricidades passiva e involuntária reflexa; normais a deglutição e contrôle de esfincteres, bem como a marcha. As várias provas para o exame da praxia resultaram normais, com exceção daquelas referentes à praxia buco-lingual. Foi observada incapacidade de mobilizar voluntàriamente a língua, apesar de não haver qualquer sinal de paralisia lingual; a paciente tinha dificuldade para projetar a língua para fora da bôca, para os lados e para cima, sob comando. Esta apraxia não era constante e se inostrava mais nítida quando as ordens eram mais complexas. Exemplos: Abra a bôca - a paciente realizou corretamente; Feche a bôca e empurre a bocheca com a lingua - a paciente foi incapaz de realizar o movimento, mesmo quando mostramos como deveria fazer, pedindo que simplesmente o reproduzisse; Ponha a lingua para fora (para a direita ou p̀ara a esquerda) - raras vêzes a menina era capaz de realizar a ordem, mesmo imitando; esforçava-se nitidamente, mas mostrava-se desanimada por não se sentir capaz. As ordens de assobiar, enrugar a testa e fechar os olhos, foram realizadas corretamente. Ordens mais complexas, como Abra a bôca e feche um dos olhos, não foram realizadas.

$O$ exame da inteligência pela bateria de Grace Arthur, de habilidade manual, mostrou nível mental bom, embora os tempos de realização das provas fôssem um pouco aumentados, mostrando-se a paciente, algumas vêzes, indecisa e um tanto ansiosa ante as provas mais complexas.

A linguagem espontânea estava muito reduzida. A mãe da paciente queixava-se de que ela "apesar de ser capaz de falar, não queria falar nada em casa". A menina, entretanto, era capaz de responder corretamente a várias perguntas, desde as comuns de identificação até outras mais complexas. Já pôde ser observado, no primeiro exame, que a dificuldade de expressão se acentuava quando as perguntas referiam-se a assuntos mais abstratos ou se referiam a situações não ligadas diretamente às do momento. Não foi notada disartria, embora a articulação fôsse algumas vêzes trabalhada, lenta e corrigida. $O$ exame pode ser assim resumido:

Exame da percepção - Foram colocados sôbre a mesa 20 cartões com figuras simples (peixe, navio, balde, casa, cachorro, etc.), pedindo-se à paciente que indi-

* Somos gratos ao Dr. Aloisio Matos Pimenta, pela gentileza em nos fornecer os dados clínicos relativos aos primeiros exames, ao ato cirúrgico e ao pós-operatório imediato desta doente. 
casse cada uma delas; ela mostrou entender perfeitamente a ordem, indicando sempre corretamente.

Em seguida, foi feito o exame da percepção da palavra escrita; juntamos aos cartões do exame anterior outros em que estavam escritos, alguns com letra de fôrma e outros em cursiva, os nomes de cada uma das figuras apresentadas, recebendo a doente a ordem de colocar sôbre cada figura o cartão onde estava $\epsilon$ scrito o respectivo nome; esta ordem também foi realizada corretamente.

A paciente podia ler frases simples apresentadas no momento, e mesmo as de uma historieta de $W$. Busch ( $O$ camundongo) ilustrada com numerosas figuras; nesta leitura observanios, algumas vêzes, um fenômeno curioso de substituição da palavra constante do texto, por uma outra de significado próximo e de uso mais comum; notamos, por exemplo, a substituição de "camundongo" por "rato".

A leitura de um trecho, mesmo simples, sem o auxílio das figuras (outra historieta de $W$. Busch da qual encobríamos as ilustrações, oferecendo apenas o texto para ser lido) era feita com extrema dificuldade, a paciente não percebendo o sentido da narrativa; uma das vêzes em que fizemos esta prova de leitura sem ilustração, ao terminar a leitura do texto, mostramos as figuras e pudemos observar, pela mímica facial, pelas interjeições, bem como pela expressão voluntária, que só então a história havia sido compreendida.

O exame da percepção de números, tanto pela palavra falada, como escrita, mostrou-se satisfatório; a paciente indicava corretamente, entre vários números escritos, aquêles que ordenávamos, e sabia qual o maior e qual o menor.

Exame da expressão - A expressão espontânea era extremamente deficiente, pois a paciente mantinha-se em silêncio quando não estimulada, tanto durante as sessões de reeducação como no lar; esta atitude era francamente contrastante com o comportamento pré-mórbido, uma vez que, segundo informações da mãe, a paciente era alegre e expansiva anteriormente. Nas primeiras sessões de reeducação não observamos, senão esporàdicamente, a paciente tomar a iniciativa para falar; nesta época ela repetia palavras e frases curtas, quando solicitada.

A expressão oral provocada foi examinada por meio de cartões com figuras simples, recebendo a paciente a ordem de dar os respectivos nomes; ela foi capaz de dizer, apenas, o nome de cinco figuras (janela, macaco, galinha, chapeu e livro), não conseguindo denominar 15 outros cartões, inclusive alguns em que havia figuras corriqueiras como cachorro, lápis, caneta, bicicleta, etc. A dificuldade de encontrar os nomes era de tipo nìtidamente amnéstico, pois, auxiliando-se por meio de cartões em que estavam escritos os nomes das figuras, a paciente foi capaz de pronunciar êsses nomes corretamente, com exceção apenas de dois em que estavam representados uma tartaruga e uma chaminé. Estas duas palavras foram encontradas desde que a auxiliamos pronunciando a primeira sílaba.

$O$ relato verbal de uma história em quadrinhos (Pedro, o malvado - W. Busch) foi absolutamente deficiente. A paciente nåo consegniu formar frases, mesmo as mais simples, limitando-se a denominar algumas das figuras representadas (menino, mãe, biscoito, patos nadando, menino correndo, menino todo sujo); não conseguimos obter frases e, muito menos, uma interpretação. A descrição era, portanto, de tipo denominativo, francamente infantil.

Em contraste evidente com esta dificuldade para a expressão verbal estimulada por uma história em quadrinhos que lhe era desconhecida, notava-se, em outras ocasiões, a capacidade de articular frases perfeitamente corretas, mesmo sob o ponto de vista gramatical. Certa vez, mostrando-se irritada com a insistência de sua mãe, que afirmava que a paciente "não queria falar", pronunciou corretamente a seguinte frase: "O senhor acha possível eu não querer falar?" Outra vez, quando a expressão era ainda muito deficiente, pronunciou a seguinte frase: "Não quero voltar para casa antes da festa", referindo-se à festa de formatura do ginásio que freqüentava. Tivemos oportunidade de anotar outras frases corretas, carregadas de colorido afetivo, ainda nesta fase de expressão deficiente. Certo dia falou "Este cabelo 'tá horroroso" e, outra vez, "Meu irmão me chateia muito". Anotamos, ainda, outras fra- 
ses dêste mesmo tipo, com caracteristicas semelhantes quanto à correção da articulação. Ao lado disto, a paciente era incapaz de responder a perguntas simples como "Você sabe que dia é hoje?" e a outras perguntas inesperadas, particularmente as não relacionadas com a situação atual. Por exemplo: P. - De que matéria vocè gosta mais na escola? R. - Matemática, não, nãa... (rindo); P. - E as outras? R. - As outras, as outras, não, não, não sei (rindo).

Foi observada, ainda, grande dificuldade para o encontro, sob comando, de sinônimos com uma historieta de Busch ( $O$ camundongo); diante de um quadro que apresentava uma cama embaixo da qual havia um urinol, perguntamos o que era aquilo, e a paciente, embaraçada, depois de algum tempo de concentração, pronunciou a primeira sílaba da expressão popular designadora do objeto (pi...), interrompendo logo após e pronunciando a palarra "vasilha".

A expressão gráfica também era muito deficiente, pois a paciente nunca pôde escrever aquilo que não conseguia falar. A paciente conseguia copiar sem erros, tanto em letra de fôrma, como passando para a letra cursiva; no entanto, entregando-lhe 20 cartões para que escrevesse espontâneamente o nome das figuras, escreveu apenas Pesxe, não reconhecendo o êrro, a não ser quando lhe foi entregue um cartão com a palavra escrita corretamente.

Incapacidade total de escrever frases espontâneamente. Sob ditado, escreveu as seguintes frases: $O$ leite tem nata; O peixe nada no mar; $A$ lata tem doce; $A$ data do aniversário. Com pequenas incorreções escreveu: Tala é a casa dos indios; Bata na craança; Eu gosto de baba. Empregamos propositadamente as palavras "nata, nada, lata, data, taba, bata e bala" visando sensibilizar a prova da escrita sob ditado; os erros foram muito poucos, $\mathrm{cm}$ contraste evidente com a incapacidade quase total de evocar e escrever os nomes das figuras dos cartros. A paciente conseguiu escrever corretamente, sob ditado, a palavra peixe, que foi escrita erradamente quando evocada pelo estímulo da figura.

A grafia de números não diferiu muito do que acima está exposto para as palavras, pois a paciente tinha grande dificuldade em evocar cifras, sendo, entretanto, capaz de escrever números, até de cinco cifras, sob ditado. Ela conseguia fazer operações muito simples de adição e subtração, desde que não fôssem de mais de duas quantidades. Por outro lado, era incapaz de resolver problemas mesmo muito simples, como o seguinte: "Uma dúzia de ovos custa cinco cruzeiros; quanto custa uma dúzia e meia?"; sabia, entretanto, reconhecer a resposta exata entre várias soluções que lhe eram dadas.

A evolução desta afasia durante o período de um inês em que observamos a paciente foi bastante favorável sob alguns aspectos. A linguagem espontânea, até o fim dêste tempo, era ainda pobre, embora fôsse melhorando progressivamente. Não podemos avaliar o quanto desta melhora pode ser atribuído ao trabalho de recducação. Esta consistiu, na primeira fase, em um refôrço do vocabulário, estimulando a evocação voluntária de várias palavras, empregando cartões com figuras, bem como vários livros ilustrados da série Busch. Logo de início procuramos, também, estinular articulações de pequenas frases, forçando, assim, a evocação de substantivos, verbos, pronomes, conjunções e preposições. Fazíamos as perguntas de modo a que não entrassem nelas os verbos que deveriam fazer parte da resposta, como por exemplo: P. - O que o camponês está fazendo com o jumento? R. - Está amarrando êle no moinho. Estes exercícios eram feitos oral e gràficamente, sendo repetidos em casa com a assistência dos familiares, durante vários períodos, que somavain, em média, cêrca de duas horas por dia.

Desde o início, era evidente a dissociação entre o bom desenvolvimento da recuperação da palavra falada e o mau desenvolvimento da escrita. Os exercícios escritos eram cheios de erros, alguns bastante grosseiros. A redação era imperfeita e mal cuidada, observando-se, mesmo, a falta de capacidade de seguir as pautas da fỏlha do caderno. A grafia era irregular, tal como a de crianças que estão sendo alfabetizadas, francamente diferente de sua caligrafia anterior. 
Aos poucos, a evocação foi-se fazendo cada vez mais corretamente para a palavra falada. Ao fim de duas semanas a paciente era capaz de formar uma sentença com determinada palavra, sem erros dignos de nota. Usávamos, sempre, palavras passíveis de confusão para exigir da paciente um esfòrço diferenciador. Demos, por exemplo, as palavras latido e listado para formar uma sentença com cada uma. Ela escreveu: Eu ouvi um latido; $O$ vestido é listado. Estas frases e outras, escritas nas mesmas condições, não eram escritas "diretamente" pela paciente: ela as pronunciava, primeiramente, em voz alta para, depois, as escrever, como se estivesse ditando para si mesma. Outras frases escritas foram as seguintes: "A casa está forrada de tapetes"; "A professora é formada". Escreveu, com ligeira incorreção: "A maça está fardado" (fenômeno de antecipação do "a" da palavra "moça"); "Estive a acamada" (introduzindo um artigo por antecipação); "A Ivitte é camarada" (intoxicação do "I" de "Ivette"). Deu-se interessante fenômeno de intoxicação quando lhe foi dada a palavra "distraída" para formar uma frase, escrevendo: "Uma pessoa distraída podi tir muita surprisa".

Mais tarde foi-lhe mandado descrever, por escrito, uma das historietas de W. Busch; o primeiro exercício dêste tipo foi realizado de forma francamente infantil. Vamos reproduzí-lo integralmente: Vejo um galo. O galo espia no caldeirão. No caldeirão tem água pode ser que tenha milho o galo tem apenas amarela. Agoras são dois galos o primeiro é amarela o segundo é carijo o carijo vuo ver o qua tinha a crista do galo e vermelha.... e assim por diante. Não será inútil recordar que a paciente, ao adoecer, freqüentava o $4 .^{\circ}$ ano do ginásio.

Ao término do mês de reeducação, época en que a paciente viajou de volta para casa, a redação já era bem mais satisfatória. Uma das historietas de Busch (Pedro, o malvado) foi assim descrita: Pedro ganhou um biscoito de sua mãe e foi no lago para ver se com o biscoito, conseguia pregar uma peça nos patos. O primeiro dos patinhos logo que viu o biscoito, veio nadando para a margem do lago.... $O$ restante da história é descrito com uma redação aproximada desta, bem mais satisfatória do que o primeiro exemplo, notando-se até o emprêgo de pontuação correta. A apresentação do exercício era, entretanto, ainda bastante má, notando-se numerosas correçōes e letra muito irregular.

A cópia e o ditado faziam-se, ao fim dêste tempo, de forma perfeitamente correta. A redação de uma carta era, entretanto, ainda extremamente deficiente, desde que se deíxasse a paciente escrever com liberdade aquilo que desejasse; numerosos erros de redação, estilo infantil, péssima apresentação, mostrando a dificuldade com que a carta fôra redigida. Uma carta escrita cêrca de um mês depois de ter a paciente interrompido os exercícios de reeducação, tem o seguinte teor, transcrevendo-se apenas as palavras não riscadas pelas numerosas correções: hoje recebi a carta de mamãe com a carta do senhor. Deve estranhar que não ir para \$. Paulo mas foi tanta preocupação quando chegei que não deu tempo. Uma semana para visitar os amigos, depois vovo morreu e fomos a Rio Claro. Uma semana de menos para estudar. Agora que estou no Rio de Janeiro já estou estudando para depois que acabar a temporada de estudos, voutar o conçuldoro. Sobre os cadernos mandarei a mais cedo posseveil. Recomenduções à sua enfermera. Despeço muito grata. Maria do Carmo.

Como se vê, a redação é de nível baixíssimo, principalmente se a compararmos com a redação da descrição estimuiada pelas figuras da historieta.

Por esta época, a capacidade de se expriınir oralmente também variava de acôrdo com o tipo de expressão. A paciente podia repetir qualquer palavra e mesmo frase, desde que não fôsse muito extensa (forma de expressão oral equiivalente à cópia); ela descrevia satisfatòriamente uma historieta, se bem que o vocabulário fôsse pobre. A linguagem espontânea era, entretanto, muito pobre, não tanto pela forma, como, e principalmente, pelo conteúdo (vocabulário muito escasso e forma monótona). A mímica facial procurava completar o que lhe faltava de capacidade expressiva verbal; esta mímica, entretanto, nem sempre se harmonizava perfeitamente com o conteúdo das frases. A expressão oral estimulada por perguntas era bem mais sa- 
tisfatória que a espontânea: a paciente respondia com vivacidade e rapidez, pràtica mente-sem distúrbio articulatório, notando-se, apenas, lapsos amnésticos; no curso de uma frase a paciente parava e ficava pensando, "procurando" a palavra que lhe faltava, chegando, algumas vêzes, a emitir alguma palavra de sentido próximo; mostrando-se insatisfeita com a palavra emitida, continuava a procurar outra mais acertada, nem sempre conseguindo usar a palavra adequada.

Comentários - Dispensamo-nos de comentar a parte não referente à afasia, por não oferecer maior interêsse no momento. A afasia que, no início, parecia ser de tipo misto expressivo-receptivo, teve esta última componente ràpidamente desaparecida, tornando-se exclusivamente expressiva. O nível mental não se alterou de maneira digna de nota. A colaboração foi sempre boa.

$\mathrm{O}$ distúrbio expressivo mostrou nítida dissociação, desde o início e durante tôda a evolução, entre a expressão oral e a gráfica. Maria do Carmo, desde que se tornou afásica, sempre falou muito melhor do que escreveu. Poderíamos corretamente empregar êste restritivo "desde que se tornou afásica"? Parece-nos que não, e êste ponto tem bastante interêsse para a análise dos distúrbios apresentados pela paciente. E evidente que, antes de adoecer, ela devia falar muito melhor do que escrevia; se não melhor, pelo menos muito mais automàticamente. É dispensável relembrar, aqui, que o aprendizado da palavra falada não sòmente precede de alguns anos o da palavra escrita, como também é objeto de um treinamento automatizante muito mais intenso. êste fator que explica o distúrbio mais intenso e duradouro da palavra escrita - atividade mais recente, menos organizada, mais voluntária - do que da palavra falada. Dentro de cada um dêstes tipos de expressão pudemos, ainda, distinguir nitidamente a dissociação entre o mais voluntário e o mais automático. $€$ as. sim, por exemplo, que a cópia - forma mais automática de grafia, de que são capazes mesmo as pessoas não alfabetizadas - era feita com bastante correção desde o início, enquanto que a redação de uma carta - forma das mais voluntárias de grafia - era muito deficiente, ainda um mês depois de suspensas as sessões de reeducação, ou seja, aproximadamente três mêses depois de instalado o quadro afásico. Em posição intermediária consideramos o ditado e a descrição de gravuras, formas de expressão mais voluntárias do que uma cópia, porém, menos voluntárias do que a redação espontânea. Há evidente superposição entre os defeitos de expressão pela grafia o pela palavra, reconhecida a dissociação apontada inicialmente entre a expressão oral e gráfica.

Não acreditamos que as dificuldades de redação corressem por conta de uma apraxia dos movimentos destinados à escrita, uma vez que as várias provas para o exame da praxia dos membros deram resultados normais.

A deficiência da linguagem espontânea parece-nos ser um dos fatos mais notáveis na observação da Maria do Carmo, explicando sua irritabilidade junto aos familiares, que, não compreendendo o fenômeno, supunham que a paciente não tinha vontade de falar. Esta deficiência, confundível com uma "teimosia" (para usar a expressão da mãe da paciente), é o que torna, muitas vêzes, estas observações difíceis e objeto de julgamentos apressados ou errôneos. $O$ observador mal avisado explica como manifestação de negativismo aquilo que é, na realidade, manifestação de uma dissociação entre as formas mais automáticas e voluntárias da linguagem. Até os últimos dias em que observamos a paciente - quando sua expressão já havia melhorado bastante sob muitos pontos de vista - a linguagem espontânea era ainda muito deficiente, mostrando a maior dificuldade para a recuperação destas formas mais voluntárias.

A extrema precariedade da apresentação de seus exercícios escritos -. que lembravam muito os exercícios de uma criança recentemente alfabetizada - constitui outro interessante argumento demonstrativo da maneira pela qual se processa a desintegração, com a volta a etapas superadas no desenvolvimento.

Caso 2 - Miguel R. (H.C. 158.153) com 6 anos de idade, brasileiro, branco, sem antecedentes dignos de menção. $€$ o décimo de 14 filhos, sendo que sete faleceram 
de várias moléstias, não esclarecidas; o nível social e econômico da família é baixíssimo. O paciente compareceu à consulta no Pronto Socorro do Hospital das Clínicas em 11-11-1949, relatando sua mãe a seguinte história: o paciente passava perfeitamente bem até o dia 9-11, quando, sem qualquer causa aparente, apresentou hipertermia e convulsões, com cianose muito intensa, mantendo-se, em seguida, inconsciente até o momento em que foi trazido à consulta. Na véspera passava perfeitamente bem, não sendo notado nada de anormal nem qualquer queixa por parte do paciente. Tratava-se de menino com desenvolvimento psicomotor normal, que na ocasião em que a moléstia se instalou, freqüentava um jardim da infância.

$\mathrm{O}$ exame clínico mostrou: estado geral muito mau; temperatura $37,8^{\circ} \mathrm{C}$ pela manhã; paciente inconsciente que, quando era manipulado no leito, apresentava crises de rigidez tônica em hiperextensão, sem movimentos clônicos. $($ exame do aparêlho respiratório mostrou presença bilateral de roncos e sibilos, com estertores bolhosos na metade inferior do hemitórax esquerdo. Fígado palpável, não muito duro, a um dedo e meio do rebordo costal. Para o lado do aparêlho circulatório nada foi notado de anormal, além de taquicardia (pulso con 120 batimentos).

O exame neurológico, praticado em péssimas condições, uma vez que não havia a menor cooperação do paciente, mostrou paciente prostrado, sem falar qualquer palavra durante o exame, reagindo com chôro débil, movendo espontâneamente os dois membros superiores e o inferior esquerdo; ñ̃o observamos movimentação do inferior direito, quer espontâneamente, quer sob o estímulo de picadas de agulha. $O$ paciente mantinha-se permanentemente em decúbito dorsal, sem passar para os laterais espontâneamente. As pálpebras estavam fortemente cerradas, e o paciente reagia às tentativas de abertura; nuca discretamente rígida, reagindo o paciente com chôro às tentativas de ventro-flexão; sinais de Kernig e Brudzinski esboçados; tono muscular diminuído de maneira geral, tanto à movimentação passiva como à palpação das massas musculares; reflexos profundos e superficiais abolidos. A deglutição era impossível, razão pela qual o paciente teve que ser alimentado por sonda gástrica.

A medida que os dias foram passando, o quadro foi-se aclarando progressivamente. A temperatura voltou ao normal ao fim de duas semanas, tendo, durante êste período, oscilado entre 37 e $38^{\circ} \mathrm{C}$. $\mathrm{O}$ contacto do paciente com o meio tornou-se melhor, conseguindo-se obter alguma colaboração para o exame neurológico. Cêrca de 15 dias depois de iniciada a moléstia, já não havia deficiência na movimentação voluntária do membro inferior direito. O paciente, ainda quase completamente privado do uso da palavra, de quando em quando levava as duas mãos à cabeça, com mímica de dor. Movia-se no leito de maneira um tanto desordenada e sem qualquer objetivo aparente, não exibindo, entretanto, qualquer movimento involuntário espontâneo. Colocado de pé, mantinha-se na posição senı exibir déficit muscular, mostrando-se, entretanto, amedrontado, agarrande-se ac observador. O tono muscular continuava fraco, tendo desaparecido completamente os sinais de meningismo notados no primeiro exame. Os reflexos profundos reapareceram, tanto nos membros superiores como nos inferiores; os patelares eram vivos, os aquilianos fracos; presentes os reflexos tricipital, bicipital e estilo-radial, sendo as respostas iguais e simétricas; reflexo nasopalpebral presente; reflexos cutâneo-abdominais vivos e simétricos; sinal de Babinski esboçado nos dois pés; ausente o sinal de Rossolimo. Ausência de "grasping reflex" ou de reflexo de sucção. Ausência de distúrbios nos territórios dos nervos cranianos, embora não se pudesse assegurar com rigor quanto aos inotores oculares em vista da deficiente colaboração. As pupilas, que no primeiro exame estavam em mídriase, mostravam-se agora em miose simétrica.

A atividade práxica do paciente era bastante deficiente. Apenas alguns atos automáticos eram realizados, tais como a manipulação de uma colhér para se alimentar. Outros atos elementares e menos automatizados não eram realizados, revelando déficit de iniciativa psicomotora. Assim, ao entregarmos uma caixa de fósforos, ordenando que acendesse um palito, o paciente permanecia longo tempo com a caixa na mão, sem tomar qualquer iniciativa para retirar o fósforo do interior da caixa; aberta a caixa pelo examinador, o paciente mantinha-se igualmente sem tomar a iniciativa 
de tirar o palito de seu interior; colocado o palito em sua mão e muito solicitado, fazia o gesto de acender, sem, entretanto, atritar o palito contra a caixa. Certa vez, um dêstes gestos coincidentemente fêz com que o fósforo acendesse; o paciente mostrou-se, então, alarmado, não tendo, porém, a iniciativa de soprar o fósforo acêso ou de lançá-lo fora. Outra vez, pusemos em sua mão um pequeno avião de brinquedo; o paciente mostrou-se logo muito interessado pelo brinquedo, mas não foi capaz de realizar a ordem de fazer o "avião voar", mesmo por imitação; em outras ocasiões, mais tarde, sem que fôsse dada qualquer ordem, encontrávamos o paciente em seu leito fazendo o avião evoluir, imitando mesmo o ruido do motor; desde que esta atividade fôsse interrompida por alguns instantes pelo observador e novamente fôsse dada a ordem para fazer a mesma coisa, tal não era mais possível. $O$ déficit de iniciativa era, então, de tal forma intenso que certa vez retiramos o avião de sua mão e o guardamos, em sua presença, na gaveta de seu criado-mudo; ordenado que retirasse o avião para brincar, o paciente manteve-se diante da gaveta, sem realizar qualquer movimento para abríla; mesmo que colocássemos sua não em contacto com a gaveta, êle se mantinha imóvel com a mão apoiada sôbre o puxador, com uma expressão um tanto ansiosa na face, sem, entretanto, chegar a abrir, mesmo quando intensamente solicitado. Observado de fora da sala, através de um vidro, notamos esta mesma deficiência de iniciativa, mantendo-se o paciente durante muito tempo imóvel diante do criado-Inudo, sem ter a iniciativa de abrir a gaveta ou de sair do local. Outra vez, colocamos o avião sôbre o leito, sob as vistas do paciente, que foi, em seguida, pôsto de costas para o leito, recebendo a ordem de se voltar e pegar o avião; a resposta foi semelhante à da prova anterior, mantendo-se o paciente durante longo tempo de costas para a cama sem tomar sequer a iniciativa de voltar-se.

Foi feita outra prova para o éxame da praxia, usando-se um martelo de pesquisa de reflexos e ordenando-se ao paciente que batesse com o mesmo um certo número de vêzes na cama; depois de muito solicitado cumpriu a ordem, sem, entretanto, respeitar a ordem quanto ao número de vêzes que deveria bater; ora batia mais vêzes, ora menos, sem parecer ter noção de quantidade. Entregando-se, depois, o aviño e ordenando-se que o fizesse voar, o paciente mostrou-se intoxicado pela ordem anterior, batendo com o avião sôbre a cama, tal como havia feito com o martelo.

O exame da linguagem mostrou interessante distúrbio. Espontâneamente, o paciente nada falava; solicitado, dava algumas respostas mostrando claramente estereotipia e ecolalia. A qualquer pergunta respondia, quase que invariàvelmente, com o seu nome (Miguel); as únicas variações obtidas eram respostas do tipo ecolálico, repetindo com articulação perfeitamente correta a última palavra que o examinador havia pronunciado, Por exemplo: P. - Você quer uma bolacha? R. - Bolacha; P. - Você quer uma parede? R. - Parede; P. - Você quer um apartamento? R. - Apartamento; e assim por diante.

Estes exames foram feitos em meados de dezembro, cêrca de um mês depois de iniciada a moléstia. Os exames realizados em fins de dezembro e princípio de janeiro revelaram algumas alterações no quadro acima descrito.

O exame neurológico, excetuañdo os distúrbios da praxia e da linguagem, era, então, inteiramente normal; neste período o paciente já não estava mais acamado e perambulava pela enfermaria sem evidenciar qualquer objetivo; chegou mesmo, algumas vêzes, escapando à vigilância dos enfermeiros, a se afastar da enfermaria, tendo uma vez sido encontrado dois andares acima no prédio do hospital, vagando sem rumo.

O exame da linguagem e da praxia era, ainda, muito dificultado devido ao fato de não se conseguir fixar a atenção do paciente demoradamente; havia, ainda, déficit da iniciativa. Em virtude disto, o exane da percepção não podia ser feito com precisão. A prova dos cartões com figuras era dificultada pelo fato do paciente não apontar para os cartões quando se ordenava; o exame feito com vários objetiros, ordenando-se ao paciente que pegasse um dêles, apresentava a mesma dificuldade, não sòmente pela razão exposta, como também porque o paciente apresentava, nesta 
época, intensa intoxicação por ordens anteriores. Transcreveremos o protocolo de um dos exames, praticado em 2-1-50, que dá idéia bem precisa de seu estado: $P$. - Como é seu nome? R. - Miguel; P. - Miguel de que? R. - Miguel Roque; P. -- Esta figura o que é? (gato). R. - Miguel; P. - Este bicho qual é? R. - Este bicho Roque; P. - Você conhece êste bicho, Miguel? R. - Miguel; P. - E um gato? R. - E; P. - Ou é um cachorro? R. - Cachorro; P. - Como é que o gato grita? R. - Miguel; P. - Como é que o gato grita? R. - O gato grita; P. - Como? R. - Ele grita assim; P. - O gato faz au-au? R. - E; P. - E o cachorro? Não responde; P. - Este bicho como se chama (borboleta). R. - O gato grita.

Êste mesmo tipo de respostas era dado para vários cartões sem que se pudesse ter a certeza de que o paciente estava reconhecendo, ou não, a figura ou mesmo entendendo a ordem. Algumas vêzes, conseguíamos obter uma resposta satisfatória, como, por exemplo: P. - Este lápis de que côr ée (não responde); P. - azul, branco, vermelho, verde? R. - Vermelho (correta).

A capacidade expressiva do paciente estava pràticamente reduzida a estas respostas estereotipadas e ecolálicas, com raríssimas respostas corretas. Não foi, portanto, sem surprêsa que, um dia, ao entrarmos na enfermaria, encontramos o paciente sentado na cama, com um tambor no colo, sôbre o qual batia, sem qualquer ritmo, a música carnavalesca "Chiquita bacana", articulando de maneira absolutamente correta tôdas as palavras do estribilho, que era repetido numerosas vêzes; a música era também perfeitamente entoada. Fizemos neste dia uma gravação em fio, não conseguindo que o paciente cantasse qualquer outra música; por mais que insistíssemos pedindo que cantasse outra qualquer, respondia-nos "Outra?" e recomeçava o estribilho de "Chiquita bacana".

O exame, repetido em fins de janeiro, mostrou algumas alterações. Não nos foi possível realizar o exame da inteligência, mesmo usando a bateria de Grace Arthur de "performance" manual. Iniciamos com a prova do "manequim", que não foi realizada, permanecendo o paciente longo tempo com as peças na mão, apesar de se mostrar evidentemente interessado pela prova.

A prova de percepção, feita com cinco cartões, mostrou respostas corretas, evidenciando ter o paciente reconhecido as figuras. A atenção mostrava-se, ainda, difusa e ràpidamente esgotável. A mesma prova, tentada com 7 cartões, despertou respostas inteiramente confusas e desorientadas.

O paciente executava algumas ordens simples (bater palmas), revelando, em seguida, duradoura intoxicação por esta ordem; isto era feito sòmente por imitação, pois, quando demos a ordem verbalmente, o paciente, em lugar de cumprí-la, passou a improvisar uma canção repetindo a palavra "palma" numerosas vêzes de maneira correta e, depois, deturpando-a até torná-la irreconhecível.

Certas ordens simples não eram executadas, nem mesmo por imitação; isto se verificou mandando fazer uma bolinha de papel on abrir uma caixinha de injeçð̃es. $O$ paciente não conseguia copiar um quadrado ou uma bola; apanhou o lápis, passando a "riscar" o papel com a extremidade sem ponta, de maneira inteiramente desordenada, devolvendo ao fím de algum tempo o lápis ao observador como se tivesse acabado de cumprir a ordem.

$O$ paciente permaneceu na enfermaria até o dia 1 de março de 1950 , quando teve alta para continuar a ser observado em ambulatório. Por ocasião da alta, o quadro havia regredido apenas parcialmente. A linguagem espontânea do paciente era quase nula, apesar de estar perfeitamente adaptado na enfermaria; durante todo o tempo de internação nem uma vez o paciente nos dirigiu a palavra espontâneamente; notamos, entretanto, numerosas vêzes, o paciente cantando espontâneamente, tanto "Chiquita bacana", como trechos de outras canções carnavalescas. Freqüentemente, improvisava canções com palavras que eram repetidas insistentemente, sof rendo deturpações à medida que iam sendo repetidas.

A linguagem estimulada melhorou parcialmente, tal como a percepção. O paciente reconhecia objetos e figuras, embora de maneira irregular e inconstante; res- 
pondia, também inconstantemente, a algumas perguntas, reduzindo progressivamente a estereotipia e a ecolalia; notava-se, porém, ainda com bastante freqüêencia, a intoxicaçđ̃o por palavras pronunciadas anteriormente.

A atividade práxica também melhorou parcialmente, muito embora ainda fôssem notados distúrbios nítidos, atenuados é verdade, porém de tipo semelhante ao acima descrito.

Não conseguimos esclarecer clinicamente o caso de Miguel $R$., apesar de numerosos exames complementares. Um primeiro exame do líquiido cefalorraqueano, praticado no dia da internação, mostrou líquor límpido e incolor, com 20,3 células (linfócitos $52 \%$, médios mononucleares $18 \%$, grandes mononucleares $10 \%$, polinucleares neutrófilos $20 \%$ ); $0,10 \mathrm{~g}$ de proteínas totais; $7,40 \mathrm{~g}$ de cloretos e $1,06 \mathrm{~g}$ de glicose por litro; reações de Pandy, de Nonne-Apelt, do benjoim coloidal, de Wassermann, de Steinfeld, de Meinicke, de Eagle, de desvio de complemento para cisticercose negativas. Novos exames de líquor, repetidos 8 dias e um mês depois, resultaram completamente normais. As reações de Wassermann e Kahn no sangue resultaram negativas. A reação de Mantoux foi negativa. O hemograma mostrou: Eritrócitos 3.000 .000 por $\mathrm{mm}^{3}$; leucócitos 7.500 por $\mathrm{mm}^{3}$; hemoglobina $9,5 \mathrm{~g}$ por $100 \mathrm{ml}$; valor globular 1,0. Fórmula leucocitária: neutrófilos $82 \%$ (bastonetes $13 \%$; segmentados $69 \%$ ); eosinófilos $1 \%$; linfócitos típicos $12 \%$, leucocitóides $2 \%$; monócitos $3 \%$. Exame de lavado gástrico o pulmonar negativo para bacilos álcool-ácido resistentes; o lavado gástrico mostron enorme quantidade de leveduras e raros filamentos micelianos, que não foram considerados patogênicos; o lavado pulmonar foi negativo para micose, tendo sido a sua cultura igualmente negativa para cogumelos, em um primeiro exame, e depois positiva para Penicilium e Streptococus mitis (grupo viridans). Eletrencefalograma: $O$ registro das regiões parietoccipitais mostrou um ritmo de base irregular, com predomínio de ondas lentas 2,5 a $4 \mathrm{c} / \mathrm{s}$, de média amplitude. A anormalidade existente é muito grande, sob a forma de ondas "sharp" 4 a $5 \mathrm{c} / \mathrm{s}$ e ondas lentas 1 a $3 \mathrm{c} / \mathrm{s}$, bilaterais. A hiperpnéia não foi conseguida. Conclusão: grande quantidade de anormalidades de tipo degenerativo, difusas, predominando nas regiões fronto-temporo-parietal esquerda e frontal direita. A anormalidade do lado direito é independente da do lado esquerdo (Dr. Arlindo Conde). O exame ocular mostrou, Papilas de limites, coloração e nível normais. Artérias e veias de calibre e curso normais (Dr. Paulo Braga Magalhães). Exame radiográfico do tórax: Transparência pleuropulmonar, seios costof rênicos, cúpulas diafragmáticas e silhueta cardiovascular normais (Dr. Fernando Chamas). Os exames radiográfico do crânio a pneumoventriculográfico nada mostraram de anormal (Dr. J. Zaclis).

$O$ paciente teve seu caso discutido em várias reunióes da Clínica Neurológica, sem que se chegasse a diagnóstico preciso. Pelo resultado do eletrencefalograma, parecia haver extenso processo, predominante no hemisfério esquerdo, mas atingindo também o hemisfério direito. O primeiro exame do líquor mostrou apenas ligeira hipercitose, com predomínio de linfócitos. O hemograma mostrava que o processo infeccioso era discreto, devendo-se recordar que o paciente, por essa época, apresentava um quadro pulmonar que poderia ser o responsável por estas alterações. $O$ exame pneumoventriculográfico permitiu excluir a hipótese de tumor ou abscesso. Assim, a observação foi classificada com o diagnóstico provisório de meningoencefalite difusa, de etiologia não determinada.

Comentários -- Sob o ponto de vista que naais nos interessa devemos salientar o grave quadro de apraxia e afasia apresentado pelo paciente, muito nítido ainda por ocasião da alta, isto é, depois de 110 dias de evolução. As características mais notáveis do quadro de apraxia eram a deficiente iniciativa psicoinotora e a intoxicação por ordens anteriormente recebidas; esta apraxia, como é b́bvio, dificultou muito a realização de algumas provas para o exame da afasia. Não obstante, pensamos poder classificar a afasia como sendo de tipo misto, expressivo-perceptivo, com predomínio (?) do componente expressivo. Como característica mais saliente da afasia apresentada pelo paciente notamos a deficiência da linguagem espontânea, que oferecia, entretanto, manifestações extremamente curiosas no que diz respeito à capaci- 
dade de cantar, reproduzindo, com a maior exatidão, a melodia e a letra de canções populares. Esta deficiência da linguagem perdurou dưrante tôda a evolução da moléstia, tendo regredido muito pouco em todo o longo tempo de observação, o que lhe confere valor prognóstico mau, de acôrdo com o que ficou dito no caṕtulo em que foi estudado o conceito de afasia em crianças. A estereotipia e a ecolalia foram evidenciadas desde o primeiro exame e notadas até a época em que o paciente teve alta. O exame da capacidade de expressão gráfica, prejudicado pelo fato de não se tratar de indivíduo alfabetizado, tornava-se mais complexo ainda pela interferência da apraxia, que não permitia ao paciente nem mesmo copiar formas simples, perfeitamente realizáveis em sua idade.

Caso 3 - Rodolfo R., brasileiro, branco, escolar, com 8 anos de idade, examinado no Pavilhão Fernandinho Simonsen e no Ambulatório da Clínica Neurológica. $O$ paciente foi atropelado por um automóvel em 20 de junho de 1941, tendo sof rido ligeira escoriação na perna direita e fratura na região parietoccipital esquerda, com solução de continuidade do couro cabeludo e perda de substância encefálica. O paciente apresentava-se semitorporoso, com hemiplegia direita e incapacidade de expressão verbal. No mesmo dia foi operado pelo Dr. Domingos Define, tendo sido retirado grande fragmento ósseo que estava afundado, e várias esquírulas que penetravam no tecido nervoso; a dura-máter estava dilacerada e o tecido nervoso subjacente se apresentava contundido; foi feita sutura da pele e drenagem. O pós-operatório decorreu sem grandes distúrbios. Houve supuração no local operado, que regrediu com curativos secos. O paciente manteve-se febril $\left(37\right.$ a $\left.38^{\circ} \mathrm{C}\right)$ até o dia 9 de julho. Nosso exame foi realizado cêrca de 40 dias depois do acidente.

$O$ exame da inteligência praticado com as provas não verbais do teste de BinetSimon, mostrou nivel mental aparentemente normal, embora as provas estivessem em grande parte prejudicadas. Rodolfo era um menino vivo, atento, alegre, com afetividade normal, mostrando-se muito colaborador durante tôdas as provas a que foj submetido. Segundo informações prestadas por sua mãe, sempre fôra alegre e irrequieto, tal como se mostrava por ocasião do exame. Freqüentava, na ocasião em que foi acidentado, o $2 .^{\circ}$ ano de um grupo escolar onde foi sempre bom aluno, acompanhando sem dificuldade o curso, apesar de ser "muito levado". Teve sempre predileção pelo desenho. Sua linguagem até a época do acidente era normal, sem qualquer particularidade digna de nota.

O exame neurológico mostrou hemiplegia direita total e desproporcional, sendo bastante intensa nos membros e discreta na face; a paresia facial era nitida quando o paciente ria, mostrava os dentes, ou mobilizava, sob comando, a comissura labial. $O$ exame do equilíbrio e da coordenação nada unostrou de anormal, estando as pesquisas prejudicadas no lado direito. Tono muscular ligeiramente aumentado nos membros direitos. Respiração, deglutição, mastigação e mímica normais. $O$ paciente conseguia andar sem apôio, com marcha típica em ceifadeira, sem movimentos associados do membro superior direito. Não existiam movimentos involuntários espontaneos. Os reflexos profundos mostraram-se nìtidamente assimétricos, com respostas mais vivas à díreita, tanto no membro inferior como no superior. Clono do pé e da rótula à direita, bem como fenômeno do automatismo pelas manobras de Marie-Foix, Babinski e das percussões repetidas. Nítida sincinesia pela manobra de Raimiste. Sinal de Babinski não muito nítido no pé direito, sendo, entretanto, nítida a resposta em extensão pela manobra de Oppenheim. Reflexos cutâneo-abdominais abolidos ̀̀ direita.

Exame da praxia - A movimentação dos membros direitos estando totalmente abolida, sòmente foi possível fazer o exame da praxia nos membros esquerdos; tratando-se, entretanto, de menino canhoto, segundo informava com tôda segurança sua mãe, as provas puderam ser feitas sem qualquer causa de êrro. $O$ paciente realizou, com tôda a segurança, as seguintes provas: 1 - Movimentos elementares sem objetos (fechar a mão, dobrar o punho, separar os dedos, movimentar a língua, inchar as bochechas, estirar os labios) sendo que apenas esta última prova revelava alguma 
deficiência, devida à paralisia facial; 2 - Atos reflexivos (coçar-se, mostrar o nariz, as orelhas e os olhos, pôr a mão esquerda sôbre a direita); 3 - Atos sem objetos com efeitos físicos especiais (assobiar, tossir); 4-Atos expressivos sem objetos (fazer continência nilitar, jogar beijos); 5 - Imitação de atos que se realizam habitualmente com objetos (bater numa porta imaginária, abrir uma porta imaginária, fazer o movimento de girar uma chave na fechadura, fazendo em seguida os movimentos opostos como se fôsse fechar a porta, bater um prego com martelo imaginário); 6 - Manipulação de objetos de uso comum (livros, caixas, etc.); 7 - Movimentos mais complexos, com ordem tríplice para ser obedecida segundo uma sequiência.

Exame da percepção - Torna-se supérfluo fazer muitas referências à percepção da palavra falada, depois de havermos exposto os resultados do exame da praxia; tôdas as ordens foram percebidas com clareza pelo paciente. A percepção da linguagem escrita era também perfeita, tanto no que diz respeito à escrita de imprensa, como a manual. $\mathrm{O}$ doente percebia corretamente côres e distinguia tamanhos $\mathrm{e}$ formas.

Exame da expressão - A linguagem espontânea foi estudada, não sòmente com o exame direto, mas também com auxílio de informações prestadas pela mãe e pela enfermeira do doente. Esta forma de expressão era paupérrima em Rodolfo: apesar de seu excelente espírito de colaboração, não conseguimos observar uma só vez o paciente falando espontâneamente. O paciente não fazia perguntas; algumas vêzes, pelo gesto e pela mímica facial, como que interrogava ou indicava seus desejos. Apesar de, em inúmeras ocasiões, dever usar a afirmação ou a negação durante as várias provas do exame, nenhuma vez o fêz espontâneaniente, sendo necessário que perguntássemos insistentemente, para que respondesse "sim" ou "não", com visível esfôrço, movimentando o membro são, como se quisesse auxiliar a expressão com o gesto. Sua linguagem espontânea se reduzia a alguns vocábulos - sim, mamã, $a b a$ (água) e pão -, além do que, algumas vêzes, articulava corretamente palavras de calão.

A repetição de palavras ouvidas era feita, embora com alguma imprecisão articulatória. Esstas tentativas de repetição eranı realizadas com visível esfôrço, notando-se que o paciente ficava francamente insatisfeito, quando percebia que a articulação não tinha sido satisfatória. Vamos dar exemplos dêstes feitos articulatórios, no exame da palavra repetida: Pápá (certo); Mámá (certo); Baba -- o b é articulado com um som próximo de $p$; Lalá - rará o $r$ é pronunciado como $h$; Gagá -- babá o $b$ é pronunciado com com próximo de $p$; Cacá - rará (hahá); Sisi (certo); Jajá - zazá; Tatá - rará (hahá); Daidá - babá; Casa - zazá; Tapa - tata; Pata papa; Pato - papo - papo - papa (procurando corrigir); MIapa - rara (hahá) - papa (procurando corrigir); Lata - rara (hahá); Pé (certo); Sapé - somá pésá - pépé - sapé (sòmente conseguiu articular, separando as sílabas); Petra pépa - papa - pépé (procurando corrigir); Café - sabá - sapí (gesto de desânimo); Mimi - bibi; Bóla - babá - bóbó - móla; Bóta - mola - bara - mora (gesto de desânimo). Esta articulaçåo verbal cheía de defeitos tinha, entretanto, de curioso, o fato de que o paciente imitava bem a entonação da voz e a cadência da articulação do observador.

O exame da palavra estimulada por meio de figuras mostrou grande deficiência, pois o paciente não conseguia denominar mesmo objetos simples de uso diário.

O exame da expressão gráfica foi, em muitos pontos, superponível ao da falada, embora, como é óbvio, a comparação ofereça dificuldades. $O$ paciente copiava algumas palavras defeituosamente, com letra muito menos clara e precisa do que a anterior ao acidente, conforme se pôde verificar, comparando-a com a de seus cadernos escolares. Sua escrita espontânea foi examinada, entregando-se ao paciente um caderno e um lápis, para que escrevesse nos momentos em que estivesse só. Pudemos decifrar algumas das palavras escritas. Uma destas palavras era meca; perguntamos ao paciente o que significava, sem obter resposta, até que, em determinado momento, Rodolfo apanhou um lápis e fêz um desenho suficientemente claro para que 
entendêssemos que se tratava de uma moça; perguntamos entăo "Moģa?", e èle alegremente assentiu com a cabeça. Outras palavras escritas espontaneamente foram Rafaol, Lucia (nomes de dois de seus irmãos), Sunta Casa (palavras impressas na folha de papel da enfermaria), mamâe, Raia (seu sobrenome) Maio ou Mario, meno (menino), las (laranjas)".

Observamos, também, alguns desenhos de paisagens e figuras humanas, feitos espontâneamente; êstes desenhos eram bastante satisfatórios, não sòmente no conjunto, como em detalhes; coinparados com desenhos anteriores à moléstia mostravani-se de nível muito inferior, pois êstes eram muito bem feitos, uma vez que o paciente tinha habilidade especial para o desenho, conforme informava sua mãe.

Foram infrutiferas as tentativas para o exame da capacidade de expressão escrita ou oral de palavras polissilábicas ou de frases; o paciente não conseguia articular ou escrever palavras com mais de duas sílabas, sendo que, nas polissilábicas, notava-se supressão de uma ou mais sílabas, tornando a palavra totalmente ininteligível. O paciente não conseguia formar frases mesmo com monossílabos e dissílabos, a menos que separasse conpletamente uma palavra de outra, tirando à frase o ritmo comum da expressão normal.

O exame retrospectivo de sua expressão gráfica pôde ser feito pelo exame de seus cadernos escolares, tendo sido possível observar-se que ela era bastante satisfatória, seja copiando, seja escrevendo sob ditado ou de imaginação. O paciente não dominava ainda com perfeição os cálculos anteriormente à moléstia atual, motivo pelo qual ficaram prejudicadas as respectivas provas.

Continuando o exame neurológico, foi feito o exame da sensibilidade, com os óbices naturais em um caso dêstes; foi possível verificar a existência de nítida estéreo-agnosia na mão direita; realizamos a prova colocando vários objetos sôbre uma mesa (lápis, chave, caixa de remédio, moedas, etc.) e, em seguida, colocando um dêles na mão do paciente, que deveria mostrar, depois, qual dos objetos havia sido objeto da pesquisa.

Evolução - O caso de Rodolfo evoluiu de forma lamentável; vímo-lo pela última vez no dia 11-8-1941, quando teve alta do Hospital; foi então examinado de maneira superficial, sem que nos fôsse possível avaliar o progresso da recuperação. Com grande surprêsa fomos informados, três dias após, que o paciente, cêrca de 24 horas depois de chegar em casa, apresentara um quadro febril intenso, com sinais de meningismo, tendo sido levado no mesmo dia para o Hospital de Isolamento, onde foi feito o diagnóstico de meningite purulenta, tendo falecido em 14-8-1941.

Comentários - A primeira característica a destacar nesta observação é o fato de que um paciente indiscutivelmente canhoto apresentou uma afasia por lesão do hemisfério esquerdo, o que contraria c assentimento generalizado que admite ser o hemisfério direito o dominante, nos canhotos, para os processos da linguagem. E claro que não dispomos de elementos absolutamente seguros para afirmar que não houvesse, no hemisfério direito, uma lesão por contragolpe, recordando-se que o paciente fôra atropelado por um automóvel, tendo recebido um choque bastante intenso. Contra êste modo de ver, pode-se argumentar, apenas, com a falta de qualquer outro sinal indicador de lesão do hemisfério direito.

$O$ paciente não apresentava qualquer distúrbio da praxia, mesmo da praxia facial. Sua afasia era de tipo expressivo, pura, sem qualquer distúrbio da percepção. Seu déficit expressivo pôde ser analisado em conjunto, tanto no que diz respeito a expressão oral, como gráfica, por serem bastante semelhantes os distúrbios. $O$ primeiro ponto em que se pode estabelecer êste paralelo, é na extrema pobreza da expressão espontânea, tanto falada como escrita. Certas perturbações são comuns à elocução e à expressão gráfica, e outras próprias de uma ou outra. Verificamos fenômenos de intoxicação (tata quando deveria falar tapa, papa em lugar de pata, baba e depois bóbó por bola), bem como fenômenos de antecipação (sama depois pesa, e depois pépé, em lugar de sapé). Na expressão gráfica, observamos fenômenos de elisão, com supressão de uma ou duas sílabas (meno em lugar de menino e las em 
lugar de laranjas). A dificuldade para a expressão de polissílabos era tão evidente na palavra falada como na escrita.

Outro fato bastante curioso vem a ser a conservação relativa da capacidade de desenhar; notemos que o desenho é uma forma de expressão anterior à grafia na evolução do aprendizado escolar (òbviamente porque a criança adquire mais precocemente disposições para desenhar do que para escrever), sendo, portanto, uma forma de expressão mais sòlidamente organizada nesta fase do desenvolvimento do indivíduo.

Notamos, ainda, outro fato curioso, que é a persistência, entre as quatro palavras que constituiam o vocabulário espontâneo do paciente, de três que são das mais primitivamente adquiridas no desenvolvimento da linguagem (evidentemente porque oferecem menores problemas articulatórios): mamã, aba (água) e pão.

Como é em geral observado, a cópia estava relativamente conservada, em contraste evidente com a escrita espontânea.

Caso 4 - Volney N. (Registro H.C. 51.784), 3 anos, brasileiro, branco, examinado na Clínica Neurológica do Hospital das Clínicas em 23-9-1949, conduzido por sua mãe, que relatou o seguinte: $O$ paciente foi sempre doentio, tendo sempre apresentado distúrbios intestinais. Cêrca de 4 ou 5 meses antes de ser levado à consulta, começou a apresentar cefaléia intensa, acompanhada de vômitos freqüentes. Aos poucos, a mãe foi notando aparecinento de um déficit motor no membro superior direito, que se foi acentuando progressivamente, ao mesmo tempo que surgiram distúrbios da fala (o paciente já falava bem, formando frases corretas; era alegre e expansivo antes da moléstia atual). Coincidindo com o aparecimento dêstes sintomas, foram seus pais notando que o menino se tornou calado, falando apenas "palavras sôltas" tais como não, mamãe, vamos, quero, etc., em franco contraste com sua linguagem anterior, que era rica, com as palavras articuladas de maneira bastante perfeita. Contou-nos a informante que o paciente gostava muito de cantar, antes da moléstia atual; tinha "bom ouvido", aprendendo com facilidade canções populares, e gostando também de inventar músicas que cantava alegremente. Detalhe curioso da anamnese foi o referente a um apetite devorador que o paciente vinha demonstrando desde há algum tempo; certos dias o paciente chegava a almoçar três vêzes: na própria casa, em casa de uma vizinha e na casa da avó. Apesar disto, foi sempre muito magro. Desde o início da inoléstia seus pais foram notando que a sua visão se ia tornando progressivamente deficiente, ao mesmo tempo que surgia um "tremor nos olhos".

O exame, por ocasião da internação, revelou estar o paciente em estado de verdadeira miséria orgânica. Extremamente emagrecido, com a musculatura hipotrófica de maneira geral, com o panículo adiposo pràticamente desaparecido e as mucosas visíveis anemiadas. O exame dos diversos aparelhos nada revelou de anormal, sendo negativa a reação de Mantoux. O estado de humor era bom, mostrando-se bastante colaborador durante a realização do exame. O membro superior direito não se movia, mantendo constante atitude de semiflexão do antebraço sôbre o braço. A face também mostrava francos sinais de paralisia do lado direito, reveláveis já à inspecção estática, mas muito mais nítidos quando o paciente ria, chorava ou falara. No entanto, o paciente conseguia manter-se de pé sem apôio, andando sem grande dificuldade; movia-se espontâneamente no leito, assumindo as posições que desejasse ou que lhe fôssem ordenadas.

O exame da motricidade voluntária mostrou hemiplegia desproporcional direita, estando muito atingido o membro superior, que não se movia, um pouco menos a face, e quase nada o membro inferior. A deficiência de movimentação do membro inferior era evidenciável apenas durante a marcha, em que se notava que o paciente não movia com tanta liberdade êste membro como o seu simétrico, e na prova de elevação do membro inferior em extensão total; nesta circunstância, o paciente auxiliava o movimento com o membro superior são, revelando ter noção do déficit motor. A pesquisa das manobras deficitárias estava prejudicada quanto ao membro superior 
direito, sendo negativas as provas de Barré e Mingazzini nos dois membros inferiores. A paralisia facial era de tipo nitidamente central. Tono muscular aumentado no membro superior direito, com hipertonia em flexão; tono normal e simétrico nos membros inferiores. Não foi obtido clono dos pés e rótulas. Ausência de sinais de automatismo e de sincinesias patológicas. A pesquisa dos reflexos profundos mostrou assimetria de respostas, sendo todos mais vivos na metade direita; o bicipital e o estilo-radial não foram obtidos no lado esquerdo, sendo, entretanto, muito nítidas suas respostas no lado direito. Sinais de Rossolimo e Mendel Bechterew ausentes bilateralmente. Reflexos nasopalpebral e oro-orbicular presentes, com respostas simétricas. Reflexos cutaneoplantares com resposta em flexão bilateralmente, sendo menos nítida a resposta do lado direito; reflexos cutâneo-abdominais com respostas simétricas. Ausência do sinal de Babinski nas mãos. Mímica normal, notando-se apenas a paralisia facial que a alterava. Deglutição, respiração, contrôle de esfincteres normais.

O exame da praxia não mostrou qualquer alteração; o paciente era capaz de realizar tôdas as ordens, desde que a paralisia não interferisse, e mostrava compreender tôdas as ordens, procurando executá-las com boa vontade e atenção.

A palavra mostrava-se francamente alterada, sendo notável a falta quase que absoluta da linguagem espontânea. O exame da percepção não mostrou qualquer alteração; o paciente compreendia bem as ordens verbais, reconhecia perfeitamente objetos a figuras, tinha noção clara de tamanho, apontando com segurança qual o objeto ou figura menor ou maior.

Expressão - A linguagem espontânea mostrava-se escassíssima e limitava-se quase que exclusivamente a uma frase, repetida oportunamente, com ênfase e articulação clara e perfeita. Foi notado, desde a internação, que o paciente tinha um apetite verdadeiramente impressionante, devorando com verdadeira ânsia os enormes pratos de comida que the eram oferecidos. Todos os dias, aproximadamente pelas dez horas da manhã, no momento em que a enfermaria, localizada próximo à cozinha do Hospital, era invadida pelo aroma dos alimentos quo estavam sendo preparados, o paciente começava a pedir comida, repetindo a frase Quero comida, de início em voz baixa e serenamente, porém, aos poucos, aumentando a intensidade da voz, uma vez que seu pedido não podia ser satisfeito no momento, dando, mesmo, a êste pedido uma tonalidade imperativa, em pouco confundida con um pranto cada vez mais forte e insistente. Chegava a ficar mais de uma hora, chorando e pedindo comida, repetindo essa única frase.

A palavra estimulada, embora também pobre, era mais variada. $O$ paciente respondia a várias questũes, com articulação de tipo infantil, empregando solıções de facilidade que já haviam sido superadas na evolução de sua iinguagem, segundo nos informou sua mãe; não formava firases, respondendo com palavras, às vêzes com o caráter de palavras-frase, sendo capaz de repetir numerosas palavras propostas pelo examinador. Exemplos: P. - Você como vai? R. -- Vou bem; P. - Seu nomo como é? R. - Volni; P. - Volnei de que? R. - Vohi Omento (Nascimento); P. - Isto o que é? R. - A mão (correto); P. - E isto? R. - O pé (correto); P. - $E$ isto? R. - Adiz (nariz); P. $-E$ isto? R. - Adeia (orelha); P. - E isto? R. - braço (correto); P. - Você pode mexer seu braço? R. - Posso; P. - Você gosta de brincar? R. - Gosto; P. - Com que? R. - Brinquedo; P. - Como se chama isto? R. - Caixinha de fófo; P. - E isto? R. - sipis (lápis); P. - Você está me enxergando? R. - Tô (Não está enxergando).

A prova de grafia de formas estava prejudicada pela idade do paciente.

Foi praticado o exame de sensibilidade, com grande dificuldade, sendo possível concluir, apenas, porém com indiscutível certeza, haver estéreo-agnosia na inão direita.

Os exames complementares forneceram os seguintes resultados: Reações de WWassermann e Kahn no sangue negativas. Hemograma: leucocitose com acentuado desvio à esquerda; neutrófilos com granulações tóxicas; eosinofilia. Reação de Mantou: (leitura com 48 horas) negativa. Exame do liqüido cefalorraqueuno: punção subocci- 
pital, não sendo possível medir a pressão; liquiiido límpido e incolor; 5 células por mım 3 (linfomononucleose); proteinas totais $0,30 \mathrm{~g}$ por litro; reações de Pandy e NonneApelt positivas; cloretos $6,70 \mathrm{~g}$ por litro; glicose $0,8 \mathrm{~g}$ por litro; reação de benjoim coloidal 00000.12221 .00000 .0 ; as demais reaçơes negativas; bacterioscopia negativa. O exame parasitológico de fezes mostrou grande quantidade de ovos de $A s$. caris lumbricoides. O exame neurocular mostrou nistagmo horizontal ao olhar direto e lateralizado; visão quase nula, pois o paciente só enxergava, imprecisamente, dedos a 20 centímetros; papilas brancas, com limites precisos. Pneumoventriculografia depois de ter a pneumencefalografia revelado situação e volume anormal do sistema ventricular: "Sob narcose foram puncionados ambos os ventrículos laterais. A insuflação de um lado e de outro mostrou estarem comunicantes estas cavidades. As radiografias mostram dilatação moderada de ambos os ventrículos laterais e ausência da maior parte do $3 .^{9}$ ventrículo, restando dêle apenas pequena cavidade representando a porção mais posterior, de forma aproximadamente em crescente, de concavidade voltada para diante. A porção frontal dos ventrículos laterais encontra-se sensivelmente levantada e moderadamente desviada para o lado direito. $O$ ventrículo esquerdo, o mais deformado e deslocado, projeta-se, em occípito-placa, sob forma elíptica, de grande eixo dirigido para baixo e medialmente. Conclusão: tumor da porção inferior do lobo frontal esquerdo" (Dr. J. Zaclis). Exame neurotorrinolaringológico: Nistagmo espontâneo, oscilatório, tipo ocular. Prejudicado o exame da audição. Não se conseguiu determinar reação nistágmica visível pela prova calórica fria (Dr. A. Corrêa).

Com êstes elementos positivou-se o diagnóstico clínico de tumor localizado no lobo frontal esqueráo, tendo sido o paciente encaminhado ao Dr. Rolando Tenuto para a intervenção cirúrgica, que foi praticada em 16-1-1950, sendo encontrado um tumor cístico de grandes proporções. Foi puncionado o cisto, sendo retirados $40 \mathrm{ml}$ de líquiido citrino e foi incisada a cápsula do tumor, sendo verificado que o mesmo se estendia para a parte profunda do lobo frontal e, em sentido posterior, em direção ao lobo temporal. Não foi possível a retirada de todo o tumor. $O$ exame anátomo-patológico mostrou tratar-se de ependimoma. Pós-operatório acidentado devido à intercorrência de edema de glote, tendo sido necessária traqueotomia. Apesar disto, o paciente restabeleceu-se ràpidamente.

Evolução - O exame praticado cêrca de um mês depois da operação, quando o estado geral já era bastante satisfatório, mostrou paciente ligeiramente melhorado com relação aos exames anteriores: a visão continuava muito baixa, apenas permitindo a percepção de vultos; a movimentação do membro superior direito se fazia um pouco melhor, mobilizando principalmente o segmento proximal; a movimentação do segmento distal, embora discreta, já era bem melhor do que anteriormente à intervenção. O paciente já conseguia bater com a ıño em um pandeiro, sem, entretanto, mobilizar os dedos; fazia a extensão e a flexão do punho, em grau muito moderado; conseguia também fazer a flexão e a extensão do antebraço sôbre o braço de maneira muito débil, mantendo quase permanentemente uma atitude de semiflexão.

A linguagem melhorou, particularmente no que diz respeito à linguagem espontânea. Vamos transcrever um exame realizado no dia 24-2-1950, que traduz bem as condições da linguagem. Notava-se o mesmo emprêgo de soluções de facilidade observado en exame anterior, porém, o paciente já falava espontâneamente numerosas palavras e frases, com sentido proposicional e perfeitamente adaptadas às situaçóes. Exemplos: P. - $O$ que $\dot{e}$ isto? R. - E um taçolo (cachorro); P. $-E$ isto? R. - Um talinho (carrinho).

Anotamos as seguintes frases, pronunciadas espontâneamente: Télo $i$ na tadêla; Você já viu meu pandelo?; Olha como eu tóco; Dona Maria veio atí. Perguntei Quem é Dona Maria? R. - minha vó. Enquanto examinava um outro paciente e ordenava que ficasse de pé no leito, Volney espontâneamente levantou-se e disse: Titio, olha como eu fico, eu sei! Observamos, por várias vêzes, neste período pósoperatório, interessante fenômeno que consistiu na forma de expressão por meio do 
canto, o paciente improvisando melodias, que eram repetidas numerosas vézes, mesmo quando estava sòzinho no quarto, não se sentindo observado; as palavras não eram muito variadas, em geral exprimiam desejos: Quero minka mãe. Quero comida. Quero minha bola. Quando sabia estar sendo observado, cantava em voz mais intensa, fazendo variações na melodia, que se conservava no fundo sempre a mesma, quaisquer que fôssem as palavras. Esta forma de expressetr-se parecia agradar muito ao paciente, que algumas vèzes parecia encantado com a própria voz, repetindo sua melodia com uma expressão da mais viva satisfação.

Por ocasião da alta, em 27-2-1950, as condiçóes da linguagem eram mais ou menos estas. $O$ tempo de permanência no Hospital foi de cêrca de 5 meses.

Comentários - Esta observação pareceu-nos digna de publicação por vários motivos, sendo o principal dêles o fato de que pudemos verificar nitidamente, em paciente de tenra idade, con desenvolvimento normal da palavra até o início da moléstia atual, a instalação de nítido quadro de afasia de expressão pura, sem qualquer componente perceptivo evidenciável. Fista afasia caracterizou-se pela sua longa duração e pelo lento processo de recuperação. As principais manifestações foram a grande redução da linguagem espontânea e o emprêyo de soluções de facilidade de tipo infantil, que já haviam sido superadas nitidamente no processo de evolução; outra manifestação curiosa foi o emprêgo do canto, o paciente improvisando melodias através das quais manifestava seus desejos.

Trata-se, também, do único caso até hoje observado por nós de uma afasia tão duradoura em tumores cerebrais em crianças; já tivemos oportunidade de observar alguns outros casos de tumores ou abscessos, com manifestações afásicas que eram, porém, discretas, fugazes e de rápida recuperação.

Em virtude das enormes proporções dêste tumor, que destruía todo o lobo frontal, invadindo tambérn o temporal, podemos supor que a linguageni do paciente deveria estar dependendo do hemisfério direito.

Não deixa de ser interessante, também, recordar que a componente perceptiva da linguagem parece ser bastante resistente aos efeitos de uma lesão, o que deve ser levado em conta ao se fazer um diagnóstico de localização, que pode ser influenciado pelo fato de não ter sido observado distúrbio da percepção.

Caso 5 - Adão J. (Registro H.C. 161.161), brasileiro, branco, escolar, com 12 anos de idade, examinado no Serviço de Neurologia do Hospital das Clínicas em 28 de fevereiro de 1950, acompanhado por sua mãe, que contava o seguinte: No dia 15 de janeiro de 1950, quando o paciente brincava em um balanço, desprendeu-se a trave de madeira em que estava suspenso êste balanço, atingindo o paciente na região temporal esquerda. O menino ficou inconsciente e foi trazido ao Hospital das Clinicas (Clínica Ortopédica), onde foi operado - - ferimento corto-contuso na regix̃o temporal com afundamento da tábua óssea - permanecendo internado durante 21 dias. Como consequiência dêste traumatismo, ficou com o membro superior direito paralisado e com dificuldade para falar. Ao sair do hospital não falava quase nada, e como não melhorasse, foi trazido ao Ambulatório de Neurologia. Antes do acidente, o paciente havia completado o $2 .^{\circ}$ ano de grupo escolar, com bom aproveitamento; escrevia e lia sem ter mostrado qualquer dificuldade no aprendizado. Falava corretamente. Era destro. Ao sair do Hospital, notou a mãe que o paciente percebia perfeitamente o que lhe falavam, bem como era capaz de ler, entendendo o que lia, sem poder, entretanto, pronunciar as palavras que lia.

Antes do exame neurológico fizemos a determinação do nivel mental pela bateria de "performance" manual de Grace Arthur, obtendo resultado satisfatório quanto à execução das provas, sendo, entretanto, o tempo de execução aumentado em tôdas as provas. Não pudemos fazer análise exata quanto ao nível mental, por não estar êsse teste aferido para crianças brasileiras. Entretanto, o trabalho do paciente mostrou características dignas de menção; êle quase não usava espontâneamente a mão direita, apesar de poder fazer uso desta mão, pois não tinha um déficit que justi- 
ficasse a sua não utilização; o paciente a mantinha como que alheia ao trabalho que estava realizando. Em muitas provas em que o uso das duas mãos era necessário, o paciente trabalhava com evidente dificuldade, até o momento em que lembrávamos que deveria usar as duas mãos; sòmente então começava a trabalhar com a mão direita. Notou-se, ainda, falta de aproveitamento de experiências fracassadas anteriormente, bem como interessante anomalia na realização dos desenhos em blocos; muitas vêzes, em lugar de realizar o desenho segundo o modêlo exibido, o doente realizava variações, improvisando desenhos muito diferentes dos modelos, reconhecendo sempre o êrro e procurando corrigir. O trabalho foi sempre desordenado em tôdas as provas, o paciente não mostrando capacidade de planificar; não obstante tôdas estas particularidades. conseguiu realizar tôdas as provas.

Exame neurológico - O paciente apresentava seqüelas de hemiplegia direita; movimentava bem os membros superiores $e$ inferiores, não sendo notada, à primeira vista, qualquer diferença entre os membros esquerdos e direitos; apenas demorando na posição as provas de Mingazzini e dos braços estendidos, é que se tornava evidente um discreto déficit dos membros direitos. A comissura labial apresentava-se discretamente desviada para a direita, quando se ordenava que o paciente mostrasse os dentes ou quando ria. 'Tono muscular normal e simétrico. Reflexos profundos com respostas normais e simétricas. Não havia clono, trepidação, nem automatismo. Reflexos cutaneoplantares em flexão bilateralmente. Não havia distúrbio da motricidade ocular. Pupilas iguais, reagindo normalmente à luz. Visão e audição normais.

O exame da praxia, realizado com algumas deficiências em virtude do déficit motor do membro superior direito, não revelou qualquer distúrbio. Praxia da face normal.

Exame da linguagem - Foi feito, em primeiro lugar, o exame da percep̧̧ão, tanto da palavra falada, como escrita, bem como da identificação de figuras. Empregamos, para o exame da percepção, um conjunto de figuras espalhadas sôbre a mesa de exame, juntamente com alguns cartões em que não havia qualquer figura, mas sim palavras escritas. As figuras usadas foram: xícara, lápis, lâmpada, borboleta, macaco, bicicleta e estojo; as palavras escritas eram as seguintes: azul, lápis e sapo. Pedimos que apontasse: "Onde está a xícara", etc., ordens que foram realizadas corretamente. Pedimos, em seguida, que indicasse onde estava escrito "azul", etc., tendo sido também estas ordens corretamente executadas.

Realizamos, em seguida, um teste apenas com palavras escritas, sem figuras, utilizando as seguintes palavras: peixe, balde, verde, estojo, xícara, chaminé, lápis, azul, bicicleta e sapo. O paciente foi capaz de apontar tôdas as palavras ouvidas. Procuramos sensibilizar a prova, perguntando por algumas palavras que não faziam parte das empregadas no teste. Assim, por exemplo, perguntamos: "Onde está escrito vermelho?". O paciente correu os olhos sôbre os cartões, e, em seguida, olhou-nos com expressão desanimada, como que duvidando de sua capacidade. Em seguida, no momento em que perguntamos "Onde está escrito azul?" mostrou-nos o cartão alegremente.

A percepção de ordkens dadas por escrito mostrou-se deficiente. Demos as seguintes ordens: abra a bóca, ponha a mão no seu cabelo, ponha o láprs preto no seu bolso. Nenhuma das ordens foi cumprida. Estas mesmas ordens dadas verbalmente foram cumpridas sem qualquer dificuldade.

Exame da expressão - O paciente era capaz de repetir palavras propostas pelo observador, denominar várias figuras e ler $\mathrm{cm}$ voz alta algumas palavras. Algumas das respostas que mostram aproximadamente as condições de sua linguagem, foram as seguintes: navio, coelho, verde (leitura), gato, janela (néla), cabra (figura e palavra escrita), cachorro (a figura representava três cachorrinhos). Foi feita a seguinte pergunta: Quê estâo fazendo os cachorrinhos? R. - Agua; P. - Fazendo água? R. - Bebendo água; P. - Será água mesmo? R. - Sopa. Mostrei em 
seguida um cartão com um balde; depois de pensar demoradamente, o paciente conseguiu encontrar a palavra: jacaré (caré), balde, lápis.

Incapacidade total de formar frases. Procuramos estimular a formação de frases, pedindo ao paciente gue descrevesse alguns quadros de um livro infantil. Conseguimos apenas obter a enumeração de alguns dos elementos do quadro: menino, menina, mulher, cachorro, mesa, gaiola, couve, passarinho. Não obtivemos a formação de uma simples frase, mesmo estimulando com perguntas.

A expressão pela palavra escrita nostrou-se ainda mais deficiente. A cópia era possível, dando-se o modélo, seja em letra de fôrma, como $\mathrm{cm}$ manual. $\mathrm{O}$ paciente escreveu corretamente frases formadas por palavras de grafia aproximada, dadas propositadamente com o fito de sensibilizar a prova. Escreveu, copiando, o seguinte: A nata na lata não mata; o nó do nosso moço não néga.

Sob ordem, mandamos que o paciente desenhasse um quadrado e uma bola, o que foi feito corretamente; mandamos, em seguida, que desenhasse um quadrado dentro de uma bola e vice-versa, tendo estas duas ordens sido realizadas corretamente. Sob ditado, o paciente não foi capaz de escrever palavras simples de uso corrente, como, por exemplo, a mãe; escreveu, com péssima grafia, algo assim: amaha. Escreveu corretamente seu prenome (Adão). A dificuldade para escrever era muito grande. Mandamos, por exemplo, que escreresse o pé; escreveu, talvez intoxicado por ordens anteriores, o ma. Parecia-nos, pela observação de sua mímica facial, que o paciente não ficava muito insatisfeito com o que acabava de escrever, por mais incompreensível que fôsse a resposta; algumas vêzes olhava-nos com uma expressão vitoriosa, como que esperando novas ordens para cumprir.

Revelou-se capaz de copiar uma figura humana desenhada na hora pelo examinador; foi, entretanto, inteiramente incapaz de fazer um desenho (perfil humano) de imaginação.

O paciente era capaz de reconhecer números; conseguia escrever números sob ditado, embora frequientemente o fizesse com incorreção; reconhecia os erros e procurava corrigí-los. Foi capaz de fazer uma soma de quatro cifras $(16,15,12,8)$; ao somar a segunda parcela do total (51) falou "5" e escreveu "2". Estava provàvelmente intoxicado, porque repetira várias vêzes "vão dois" durante a execução da soma. Não conseguia realizar outras operações um pouco mais complexas; demorava muito pensando e, ao fim de algum tempo, mostrava-se desanimado, parecendo não ser capaz de fixar a atenção.

Evolução - Iniciamos os exercícios de reeducação procedendo no sentido de reforçar o vocabulário, empregando vários livros com gravuras, ordenando ao paciente que desse o nome de cada uma. Fm seguida, os exercícios foram encaminhados no sentido de formação de pequenas frases.

O exame repetido no dia 17-4-1950 não mostrou grandes alterações com relação aos exames anteriores. Embora o vocabulário fôsse mais rico, persistia a incapacidade total de formar frases, sendo as descrições dos quadros de tipo enumerativo. Linguagem espontânea nula durante o exame, e quase nula $\mathrm{em}$ casa.

Comentários - Caso típico de afasia de expressão em seguida a traumatismo craniano na região temporal. Notável deficiência da expressão espontânea. Linguagem de tipo francamente infantil, correspondente ao periodo enumerativo, sem formação de frases. Percepção sem defeitos dignos de nota no que diz respeito à palavra falada e com alguns defeitos no que diz respeito à palavra escrita. Grafia também francamente infantil, com capacidade de realizar cópia, grande deficiência na realização de escrita sob ditado e incapacidade total de escrever espontâneamente. Incapacidade de desenhar espontâneamente, a menos que fôssem desenhos de formas simples (quadrado, bola); capacidade de copiar desenhos.

Evolução muito lenta. O exame praticado três meses, aproximadamente, depois do acidente, revelou franca deficiência da expressão verbal. 


\section{CONSIDERAÇOES GERAIS SOBRE A AFASIA EM CRIANÇAS}

A análise de nossas observações permite tecer algumas considerações sôbre a forma pela qual a afasia se apresenta nas crianças.

Um primeiro ponto a chamar a atenção seria o da freqüência com que incide êsse distúrbio; ainda que nosso trabalho vise a estabelecer algo de positivo a respeito, terá um valor pelo menos indicativo, principalmente porque nossa experiência vem ao encontro da de Gutman. Julgamos que a afasia em crianças não é tão rara como se poderia deduzir de algumas publicações. Dos 5 pacientes, 4 nos procuraram entre os meses de setembro de 1949 e janeiro de 1950, num período de cinco meses, portanto. E' certo que êste fato, por si só, não constitui argumento conclusivo; êle é, entretanto, sugestivo de que a afasia em crianças é uma eventualidade clínica que está longe de poder ser considerada como raridade.

Assim, como entender o fato de que tenham sido publicadas tão poucas observações e o assunto seja tão pouco estudado? Queremos crer que a dificuldade da abordagem dos pacientes explica, em grande parte, o pequeno número de observações. Um dos problemas primordiais da neuropediatria é a tomada de contacto com os pacientes; com raríssimas exceções êles se apresentam inicialmente amedrontados, inseguros, recusando-se a colaborar de qualquer forma. Nossa experiência mostra que sòmente ao fím de 3 ou 4 dias de adaptação na enfermaria é que, em geral, as crianças se dispõem a colaborar. Esta dificuldade, inerente a tôda a Clínica Pediátrica, mostra-se mais evidente no exame neuropsiquiátrico, exame que exige maior colaboração do paciente, solicitado a participar do exame de maneira muito mais ativa do que durante um exame clínico geral. Veremos, adiante, que um dos fatos mais salientes no quadro clínico da afasia em crianças é a extrema deficiência da expressão espontânea, o que torna a abordagem ainda mais difícil, dando margem a que esta deficiência possa ser interpretada como falta de disposição colaboradora dos pacientes, tirando o entusiasmo do observador para o prosseguimento do exame. Este obstáculo é muito mais sério nos exames feitos em ambulalório, circunstância em que o diagnóstico se deve basear, quase que exclusjvamente, nas informações familiares, que nem sempre primam pela objetividade.

O que há, na realidade, como assinalou West, é falta de conhecimento do quadro clínico da afasia em crianças. E' provável que os pacientes mais jovens sejam mais resistentes do que os adultos ante o aparecimento dêste sintoma; é possível que, em certas eventualidades clínicas, como os tumores e traumatismos crânio-encefálicos, que, com certa freqüência, determinam afasia em adultos, a produção de afasia quando se trate de crianças seja menos freqüente, como ficou demonstrado pela estatística de Sorrel e col. Alie-se a êste fato o desconhecimento que se tem a respeito do quadro clínico da afasia em crianças e teremos uma explicação para a escassez dos estudos a êsse respeito.

Dentre as manifestações da afasia em nossos pacientes, destacou-sì um elemento que dominou todos os demais, pelo menos durante as primeiras 
fases em que a afasia se manifestou. Verificamos, em nossos pacientes, uma grande redução da expressão espontânea, em contraste evidente com a percepção, que se mostrou em todos os casos pràticamente inalterada, com exceção do paciente Miguel R., no qual intensa apraxia prejudicou $z$ observação dêste elemento. A deficiência da expressão espontânea nos pacientes alfabetizados se manifestava na fala e na escrita, sendo que esta se mostrou sempre mais atingida, como foi possivel verificar em tôdas as formas de expressão estimulada.

Pudemos, algumas vêzes, surpreender, no quadro de quase mutismo determinado pela deficiente expressão espontânea, raras palavras e frases sôltas, algumas vêzes traduzindo desejos imperiosos (Faz favor, dá água!, Quero comida!), outras vêzes evidenciando estados de irritação. (Este cabelo 'tá horroroso! ou Meu irmão me chateia muito) e, mesmo, palavras de calão pronunciadas por um paciente provàvelmente habituado a usar esta forma inferior de linguagem. Não notamos, em qualquer de nossos pacientes, a ocorrência de formas de expressão esporádicas transmitidas pela escrita, assim como nunca observamos a capacidade de escrever aquilo que não podiam falar, enquanto que numerosas vêzes foi verificado o fato de que os pacientes não conseguiam escrever aquilo que podiam falar.

Chamou sempre nossa atenção a correção com que estas frases esporádicas eram emitidas, sem defeitos de articulação e, algumas vêzes, mesmo gramaticalmente corretas, como a frase citada no caso da paciente Maria do Carmo S.: O senhor acha possível eu não querer falar?

Não observamos, em nenhum de nossos casos, a İogorréia verificada com certa freqüência nos pacientes adultos afásicos, observação esta válida, não sòmente para os casos aqui apresentados, como também para outros que temos acompanhado, confirmando, assim, mais esta verificação de Gutman.

As emissões estereotipadas, observadas com certa freqüência nos adultos, foram notadas com muita nitidez em um de nossos casos (Miguel R.); em outro (Maria do Carmo S.), foi notada durante alguns dias, no período pós-operatório, uma emissão estereotipada "Eu quero...Eu quero...", cujo sentido não pudemos apreender na falta de seu objeto, e que pode ser considerada como uma estereotipia em face do caráter insistente com que era repetida. Note-se, entretanto, que estas estereotipias diferem daquelas encontradas em geral no adulto, pois, nestes últimos, as palavras ou frases não têm qualquer sentido possivelmente reconhecível, como se a "caixa de música" estivesse emperrada e ficasse repetindo sempre a mesma melodia, sem qualquer relação com as circunstâncias do momento.

No terreno da expressão espontânea merece referência especial a curiosa observação feita no caso Miguel R.; êste paciente, quando ainda inteiramente privado da palavra espontânea, certo dia pôs-se a cantar — articulando tôdas as palavras de maneira absolutamente correta - o estribilho de uma canção carnavalesca. Esta linguagem é de tipo inferior em comparação com os exemplos citados acima de emissões ocasionais, nos quais se reconhece um sentido proposicional e perfeita adaptação às circunstâncias desencadeantes. Esta capacidade de cantar uma canção carnavalesca, em 
paciente completamente privado da palavra espontânea, pode ser melhor compreendida se recordarmos que o menino esteve internado durante o período de carnaval, sentindo-se provàvelmente estimulado pelas músicas ouvidas no aparêlho de rádio instalado na enfermaria, com o que se desencadeou, automàticamente, a elocução de uma canção já aprendida anteriormente, provàvelmente repetida muitas vêzes antes da eclosão da doença. A linguagem dêste paciente era, nesta época, reduzida pràticamente à estereotipia - $M i$ guel - com que respondia a tôdas as questóes, variando apenas quando respondia repetindo a última palavra pronunciada pelo observador (ecolalia).

A expressão estimulada mostrou-se atingida de maneira semelhante em todos os pacientes. Nos casos em que foi possível observar, notamos evidente dissociação entre os distúrbios da palavra falada e escrita, sendo esta sempre mais atingida. Em ambas as formas de expressão notamos, também, que certos usos da linguagem estavam ainda mais atingidos do que outros. Assim, por exemplo, no que diz respeito à expressão oral, notamos sempre a capacidade de repetir algumas palavras, e mesmo pequenas frases em alguns casos, com exceção do paciente Miguel R., que respondia sempre com a estereotipia ou com a ecolalia. Considerando-se a repetição de palavras como um dos empregos mais elementares da fala, seria justo esperar que esta fôsse a menos atingida. A denominação de objetos ou figuras, forma mais voluntária de expressão, mostrou-se sempre mais deficiente do que a repetição pura e simples de palavras. Em alguns casos esta dissociação foi muito evidente. A paciente Maria do Carmo S. era capaz de repetir qualquer palavra que lhe fôsse proposta, ao passo que, no exame da expressão estimulada por figuras, não conseguiu denominar mais do que 5 entre 20 figuras, apesar delas representarem animais e objetos dos mais corriqueiros.

Analisando os resultados observados no uso mais complexo da linguagem, qual seja o de descrever uma história em quadrinhos, nunca obtivemos resposta melhor do que uma simples enumeração das figuras representadas nos quadros, tipo de resposta correspondente à idade de três anos no teste de Binet-Simon. Esta manifestação foi muito evidente no caso da paciente Maria do Carmo S., tendo sido verificada uma regressão muito rápida, coun retôrno a uma situação próxima da normal. No caso Adão J.. decorridos cêrca de 3 meses após a instalação do quadro afásico, havia ainda um déficit considerável, pois o paciente era incapaz de descrever os quadros simples de um livro infantil no qual estão representadas, em vários quadros, as atividades diárias de dois irmãos.

Vemos, por esta análise, que, na observação de um caso de afasia, não podemos encarar o déficit expressivo de maneira global, sem distinguir as variadas formas pela qual a palavra pode ser utilizada. O emprêgo de uma forma espontânea foi verificado várias vêzes, porém, sempre com o caráter de uma expressão automática, desencadeada por fatôres de ordem emocional ou por necessidades imperiosas. A expressão provocada mostrou-se possível quando era de tipo inferior (repetição de palavras ou frases), tornan- 
do-se progressivamente mais deficiente à medida que procurávamos estimular um tipo de expressão superior, como seja a descrição de uma história em quadrinhos.

A expressão pela grafia foi sempre muito mais deficiente do que a expressão oral nos três pacientes em que foi possível fazer o exame por já estarem alfabetizados. Aqui, como na expressão oral, cabe distinguir entre as formas mais superiores e mais inferiores de grafia. As mais inferiores, conseqüentemente mais automáticas, mostravam-se muito menos atingidas pelo déficit; a forma mais inferior, que é a cópia, mostrou-se possível em todos os pacientes, enquanto que as mais superiores, como a descrição de uma história em quadrinhos, ou mais ainda, a redação de uma carta, mostraram-se intensamente atingidas.

Todos êstes fatos, destacados da observação de nossos pacientes, conduzem francamente para uma única interpretação do distúrbio. Sòmente através da concepção jacksoniana poderemos compreender o fato de que um paciente inteiramente privado da palavra voluntária, seja capaz de cantar, articulando perfeitamente tôdas as palavras, o estribilho de uma canção popular, ou que outro saja de seu mutismo para articular palavras de calão e que outro seja capaz de perguntar $O$ senhor acha possível eu não querer falar?

Que outra explicação poderia ser proposta para esta dissociação entre os empregos da palavra falada e escrita, esta sempre muito mais atingida? Salta aos olhos que, sendo a escrita muito mais recente, menos organizada e, portanto, mais voluntária do que a palavra falada, encontrâmo-la mais atingida exatamente pelo fato de que, sendo menos automatizada, está mais exposta à ação danosa da lesão, tal como se observa em outras manifestações de desintegração de funções nervosas.

E' perfeitamente possível a qualquer um de nós — em auto-observação - encontrar provas da validez desta interpretação. Cito, a propósito, um fato verificado comigo mesmo, que verifiquei ter sido anotado também por Nielsen, e que me parece muito comum, pois vários colegas, por mim consultados, referiram ter feito idêntica observação. Aprendi datilografia muito pouco e muito mal, e tenho escrito à máquina sempre com muita dificuldade; é freqüentíssimo não conseguir escrever diretamente à máquina certas palavras de uso comum, por não me recordar, no momento, qual é a sua grafia correta. Torna-se necessário, para solucionar esta dificuldade, abandonar a máquina e escrever a palavra à mão, para depois datilografá-la. O lapso só pode ser corrigido recorrendo a um automatismo mais organizado, uma vez que êle atinge os usos mais recentes e menos organizados da palavra. Quem é que já não teve oportunidade de verificar uma criança fazendo exercícios escolares, repetindo para si mesma, em voz sussurrada e mesmo em voz alta, as palavras que está escrevendo, como que reforçando esta atividade mais recentemente adquirida?

Ainda dentro do mesmo espírito interpretativo, podemos apontar o fato de que os distúrbios perceptivos parecem ser bem mais raros do que os expressivos nas crianças. De acôrdo com a observação leiga corrente, con. 
firmada pelos estudos especializados, é fato incontestado que a percepção da linguagem é uma atividade que precede a capacidade de expressão, conforme já expusemos em capítulo anterior. Acreditamos que o menor sofrimento do elemento perceptivo nas afasias, bem como sua recuperação mais rápida, decorrem de seu desenvolvimento mais precoce, que o torna mais organizado e automático do que o elemento expressivo, mais recentemente adquirido.

Temos acompanhado vários casos de afasia em pacientes adultos e verificado manifestações semelhantes no que diz respeito à dissociação entre a palavra falada e escrita, nunca, porém, com a pureza apresentada em algumas destas observações feitas com crianças. A explicação desta diferença entre a criança e o adulto parece-nos simples, se recordarmos que o adulto já automatizou também a escrita. Temos já feito algumas observações, à primeira vista contraditórias. Recentemente, tivemos ocasião de acompanhar o caso de um grande escritor brasileiro, acometido por um quadro de afasia mista. Certo dia, quando procedíamos a uma sessão de reeducação da linguagem, o paciente, irritado por não conseguii escrever uma palavra que havia sido ordenada, tomou o lápis e escreveu corretamente $E u$ sei escrever mas não consigo. A única explicação para êste fato reside na automatização da escrita em um homem que durante tôda a vida trabalhou escrevendo. Em crianças, nunca seria possível uma verificação dêste tipo.

Em face do pequeno número de nossas observaçōes, bem como levando em conta o fato de que estiveram em jôgo etiologias diferentes, não nos sentimos autorizados a apontar características distintivas entre as afasias das crianças mais jovens e mais idosas. Podemos, porém, da análise de conjunto destas observações, salientar alguns elementos que podem ser apontados como conclusões de nosso trabalho.

\section{SUMARIO E CONCLUSÖES}

0 autor, depois de rápida revisão bibliográfica, pôde verificar que são escassos e contraditórios os trabalhos sôbre a afasia em crianças. Desenvolvendo seu trabalho, expõe, inicialmente, as várias etapas do desenvolvimento da linguagem, e em seguida, analisa os vários conceitos existentes sôbre a afasia. Em outro capítulo põe em destaque as principais características da afasia em crianças, salientando as diferenças existentes entre a chamada "afasia de evolução" e a afasia adquirida.

Apresenta cinco observações de afasias verificadas em crianças: 3 póstraumáticas, uma conseqüente a tumor de localização frontotemporal esquerda e outra relacionada com processo infeccioso rotulado como meningoencefalite difusa. Estas observações foram analisadas à luz do conceito jacksoniano, chegando o autor às seguintes conclusões:

1) A principal característica da afasia apresentada por êstes pacientes foi a deficiência da linguagem espontânea.

2) Não foi verificada a logorréia, tão frequientemente observada nos adultos. 
3) Não foi verificada disartria, a menos que sejam consideradas como tal as soluçóes de facilidade observadas em alguns casos.

4) As observações coincidem com as de Gutmann no sentido de que os distúrbios perceptivos são muito escassos em confronto com os expressivos.

5) Foram freqüentes os lapsos de tipo amnéstico, ao contrário do que observou Gutmann.

6) Há nítida dissociação entre os empregos automáticos e voluntários da linguagem, êstes muito mais atingidos do que aquêles, tanto na palavra falada como na escrita.

7) A grafia - forma de expressão mais voluntária do que a palavra falada - foi muito mais severamente atingida. balhosa.

8) A duração do distúrbio foi longa e a recuperação, lenta e tra-

9) Os distúrbios da grafia recuperaram-se mais lentamente do que os da palavra falada.

10) A interpretação proposta por Hughlings Jackson parece ser a única capaz de explicar os aspectos aparentemente contraditórios dos quadros afá. sicos observados.

\section{SUMMARY AND CONCLUSIONS}

After a brief bibliographic review, the author had the opportunity of verifying how scanty and contradictory were the works on children aphasia. He begins by exposing the different steps of the development of the language; next he analyses the various existing notions about aphasia. In another chapter he shows the principal characteristics of aphasia in children, enhancing the differences between the so-called "aphasia of evolution" and acquired aphasia.

He presents five observations of aphasia in children: 3 post-traumatic, one the result of a left frontotemporal tumor and the other related to an infectious process supposed to be a diffuse meningoencephalitis.

Analysing these observations according to Jackson's ideas the author reaches the following conclusions:

1) The main characteristic of aphasia in our patients was the deficiency of spontaneous language.

2) The logorrhea, so often observed in adults, was not recorded in our patients.

3) It was not registered dysarthria, unless we consider as such the solutions of facility found in some cases. 
4) The troubles of perception are rare in comparison with those of expression and in this concern our observations are in accordance with those of Gutmann.

5) The lapses of amnestic type were frequent in our patients, in disagreement with Gutmann's observations.

6) There is a sharp dissociation between the automatic and voluntary uses of language, the latter much more troubled than the former, both in spoken and written word.

7) The written language - a much more voluntary form of expression - is much more severely disturbed.

8) The duration of the disturbance was long and the recovery slow and difficult.

9) The disturbances of the written language improved slower than those of the spoken language.

10) Hughlings Jackson's interpretation seems to be the only one capable of explaining the apparently contradictory aspects of the aphasic pictures of our patients.

\section{RESUME ET CONCLUSIONS}

Après avoir fait une rapide revision bibliographique, l'auteur a pu vérifier que les travaux sur l'aphasie chez les enfants sont rares et contradictoires. Il expose d'abord les plusieurs étapes du développement du langage et analyse ensuite les plusieurs concepts existents sur l'aphasie. Dans un autre chapitre, il fait ressortir les principales caractéristiques de l'aphasie chez les enfants, faisant ressortir les différences existentes entre ce que l'on appelle "aphasie d'évolution" et aphasie acquise.

Il présente cinq observations d'aphasies vérifiées chez des enfants: 3 post-traumatiques, une conséquente à une tumeur de localisation fronto-temporale gauche et une autre se rapportant à un procès infectieux intitulé comme méningo-encéphalite diffuse. Ces observations sont analysées à travers l'interprétation jacksonnienne. L'auteur arrive aux conclusions suivantes:

1) La principale caractéristique de l'aphasie chez nos malades a été l'inaptitude au langage spontané.

2) La logorrhée, si fréquemment observée chez les adultes, n'a pas été vérifiée chez nos malades.

3) La dysarthrie n'a pas été vérifiée, à moins que nous considérions comme telle les solutions de facilité observées dans quelques cas.

4) Nos observations coïncident avec celles de Gutmann, les troubles perceptifs étant très rares, comparés aux troubles expressifs. 
5) Le laps du type amnestique ont été fréquents chez nos malades, Gutmann ayant observé le contraire.

6) Il y a une dissociation nette entre les emplois automatiques et volontaires du langage, ceux-ci étant beaucoup plus atteints que ceux-lá, autant pour l'expression orale comme pour l'écrite.

7) La graphie, forme d'expression plus volontaire que la parole est bien plus sévèrement atteinte.

8) La durée du trouble a été longue et la récupération, lente et ardue.

9) Les troubles de la graphie se sont récupérés plus lentement que ceux de l'expression orale.

10) L'interprétation proposée par Hughlings Jackson paraît être la seule capable d'expliquer les aspects apparemment contradictoires des cadres aphasiques de nos malades.

\section{BIBLIOGRAFIA}

1. Ombredane, A. - Iátudes de psychologie médicale. I: Perception et langage. Atlântica Ed., Rio de Janeiro, 1943.

2. Borges-Fortes, A. - $O$ problema das afasias. Tese apresentada à Fac. Med. da Univ. de Pôrto Alegre para concurso de catedrático de Clínica Neurológica, 1943.

3. Year-Book of Pediatrics. H. G. Poucher Ed., Chicago, 1940-1948.

4. Nielsen, J. M. - Agnosia, apraxia, aphasia. P. B. Hoeber Edit., Nova YorkLondres, 2.4 Edição, 1946.

5. MacCarthy, D. - - Desarrollo del lenguage. In Manual de Psicologia del Nifio (C. Murchinson). Trad. castelhana, F. Seix Editores, Barcelona, 1935.

6. Piaget, J. - Le Langage et la Pensée chez l'Enfant. Neuchatel Ed., Paris, 1924.

7. Boujarde, J. - L'Intelligence et la Pensée chez l'Enfant (Nouvelle Encyclopedie Philosophique). F. Alcan Ed., 1937.

8. Marinho, H. - A linguagem na idade pré-escolar. Instituto Nacional de Estudos Pedagógicos, Boletim n.: 27, 1944.

9. Feyeux, A. - L'Acquisition du Langage et ses Retards. N. Maloine Ed., Paris, 1932.

10. Ombredane, A. - Le Langage. In Nouveau Traité de Psychologie (George Dumas), Alcan Ed., Paris, 1930.

11. Ajuriaguerra, J. e Hécaen, H. - Le Cortex Cérébral. Masson et Cie. Ed, Paris, 1949.

12. Gesell, A. e Amatruda, C. S. - Developmental diagnosis. P. Hoeber Ed., Nova York, 1941.

13. Froment, J. - Langage Articulé et Fonction Verbale. In Traité de Physiologie Normale et Pathologique. Vol. 10. Masson Cie. Ed., Paris, 1935.

14. Dejerine, J. - Sémiologie des Affections du Systéme Nerveıx. Masson Cie. Ed., Paris, 1926. 
15. Jackson, J. H. - Selected Writings. Vol. 2. Hodder e Stougleton Ed., Londres, 1932.

16. Low, A. - Studies in infant speech and thought. Univ. of Illinois Bul., 33:39 (maio) 1936.

17. Monakow, C. V. e Mourgue, R. - Introduction Biologique à l'Etude de la Neurologie et de la Psychopathologie. F. Alcan Ed., Paris, 1928.

18. Alajouanine, T., Ombredane, A. e Durand, M. - Le Syndrome de Désintegration Phonétique dans l'Aphasie. Masson et Cie. Ld., Paris, 1939.

19. Pinto Pupo, P. - Aspectos Neurológicos do Coma Insulínico. Tese de Concurso à Docência, S. Paulo, 1942.

20. Longo, P. W. e Lefèvre, A. B. - Considerações a propósito de cinco casos de afasia motora. Arq. Neuro-Psiquiat., 3:249-257 (setembro) 1945.

21. Lefèvre, A. B. - Considerações sôbre a reeducação de un caso de afasia motora. Resumo publicado na Rev. Paulista de Med., 36:255 (março) 1950.

22. Weisenburg, T. H. $-\Lambda$ study of aphasia. Arch. Neurol. a. Psychiat., 31:1-33 (janeiro) 1934.

23. Wilson, S. A. K. - Neurology. Williams a. Wilkins Ed., Baltimore, 1940.

24. Purves-Stewart, J. - I.e Diagnostic des Maladies Nerveuses. G. Doin Ed., Paris, 1939.

25. Kroll, M. - Los Síndromos Neuropatológicos. Diagnóstico diferencial de las enfermedades nerviosas. Trad, castelhana M. Uson Ed., Barcelona, 2.4 Ediৎ̧̃̃o, 1946.

26. Granich, L. - Aphasia (A guide to retraining). Grune e Stratton Ed., Nova York, 1947 .

27. Barraquer-Ferré, L., Gispert Cruz, I. e Castañer Vendrell, E. - Tratado de Enfermedades Nerviosas. Salvat Ed., Buenos Aires-Barcelona, 1936.

28. Walshe, F. M. R. - L.es Maladies du Système Nerveux. Trad̀ francêsa. Masson et Cie. Ed., Paris, 1948.

29. Nielsen, J. M. - A 'Textbook of Clinical Neurology. P. Hoebber Ed., Nova York-Londres, 1943.

30. Brock, S. - Bases da Clínica Neurológica. Trad. brasileira Publ. Pan-Americanas Ed., Rio de Janeiro, 1945.

31. Grinker, R. R. e Bucy, P. C. -- Neurology. Ch. C. Thonas Ed., Springfield, 1949.

32. Litter, M. e Wexselblatt, M. - Tratado de Neurologia. El Ateneo Ed., Buenos Aires, 1939.

33. Bing, R. - Les Maladies Nerveuses en 30 Leçons. Atar e Maloine Ed., Genève-Paris, 1924.

34. Angyal, L. - Aphasia and cathegoric behaviour. Monat. f. Psychiat. u. Neurol., 119:45-54 (janeiro) 1950.

35. Wernicke, C. - La Síndrome Afásica. In La Clínica Contemporanea (I.eyden, E. V. e Klemperer, F.) Trad. italiana. Soc. Ed. Libraria Milão, 1908.

36. Dimitri, V. - Afasia (Estudo anátomo-clínico). El Ateneo Ed., Buenos Aires, 1933.

37. Delacroix, H. - Liaphasie selon Henry Head. J. de Psyclıol, 15:283 (abril) 1927. 
38. Travis, L. E. - Speech Pathology. D. Appleton Century Ed., Nova YorkLondres, 1931.

39. Judson, S. I. e Weaver, A. T. -- Voice Science. F. S. Crotis Ed., Nova York, 1942.

40. Ford, F. R. - Diseases of the Nervous System in Infancy, Childhood and Adolescence. Ch. Thomas Ed., Springfield, 194.

41. Kanner, I. - Child Psychiatry. Ch. Thomas Ed., Springfield, 1942.

42. Trammer, M. - Manual de Psiquiatria Infantil. X. Morata Ed., Madrid, 1946.

43. Robin, G. - Précis de Neuro-psychiatrie Infantile. G. Doin Ed., Paris, 1939.

44. Roncal, P. - Manual de Neuro-psiquiatria Infantil. Casa de España Ed., México, 1940.

45. Ibrahim, J. - Doenças Orgânicas do Sistema Nervoso. In Tratado de Pediatria (Pfaundler, M. v. e Schlossmann, A.). Trad. brasileira, vol. 7.*, Guanabara Ed., Rio de Janeiro, 1940.

46. Gareiso, A. e Escardó, F. - Manual de Neurologia Infantil. El Ateneo Ed, Buenos Aires, 1942.

47. De Santis, S. - Neuropsiquiatria Infantile. A. Stock Ed., Roma, 1925.

48. Shirley, H. F. - Psychiatry for the Pediatrician. The Commonwealth Fund Ed., Nova York, 1948.

49. Travis, L. F. - Patologia del Lenguage. In Manual de Psicologia del Niño (Carl Murchinson), Trad. castelhana pág. 813-874, F. Seix Ed., Barcelona, 1935.

50. West, R. - Aphasias. In Brennemann: Practice of Pediatrics. Vol. 4, W. F. Prior F.d., Maryland, 1949.

51. Ley, J. - L'alexie et l'agraphie d'évolution. Etude de six cas. L'Encéphale, 26:429-437 (junho) 1931.

52. Ley, J. e Tordeur, G. W. - Alexie et agraphie d'évolution chez de jumeaux monozigotiques. J. Belge de Neurol. et Psychiat., 36:203-222, 1936.

53. Irwin, R. B. - Speech comes to a five year old boy. J. Speech Dis., 11:197-203 (setembro) 1946.

54. Mantero, M. E. e Hazan, J. - Afasia adquirida en el niño. Arch. Pediat. Uruguay, 10:73-87, 1939.

55. Heuyer, G. e Lèdovici, A. - Hémiplegie droite avec aphasie chez un enfant de 7 ans. Rev. Neurol., 79:40-42 (janeiro) 1947.

56. Heuver, G., Duchene, H. e Roumajon, Y. - $\boldsymbol{\Lambda}$ propos d'un cas d'aphasie après hémiplégie congénitale, avec dégénerescence maculaire associée. Considérations sur certains retards de la parole chez l'enfant. Rev. Neurol., 77:31-33 (janeiro) 1945 .

57. Girardier, J. e Jeannin, J. - Fracture du crâne accompagnée d'aphasie après intervalle libre, chez un enfant de 7 ans. Lyon Chir., 36:183-189 (março-abril) 1939.

58. 'I'homas, A., Sorrel, E. e M. Sorrel-Dejerine - Un cas d'aphasie motrice par traumatisme cranio-cérébral chez l'enfant. Rev. Neurol., 63:893-896 (junho) 1935.

59. Gutman, E. - Aphasia in children. Brain, 65:205-219 (junho) 1942.

60. Nance, L. S. - Differential diagnosis of aphasia in children. J. Speech Dis., $11: 219-223$ (setembro) 1946 . 